\title{
REFLEXIONES SOBRE LA EVOLUCIÓN LEGISLATIVA Y JURÍDICA DE LOS DERECHOS DE LAS MUJERES EN ESPAÑA: DESDE LA SEGUNDA REPÚBLICA HASTA LA ACTUALIDAD
}

\author{
Dan Stanforth \\ University of Denver \\ Aurelio Santana Rodríguez \\ Universidad de La Laguna \\ José Andrés Salgado Fernández \\ Doctor en Derecho \\ Letrado de la Administración de Justicia-Tribunal Superior de Justicia de Galicia
}

\section{RESUMEN}

Este trabajo ofrece un análisis detallado de los desarrollos legislativos y judiciales con respecto a los derechos de las mujeres en España desde la Segunda República hasta la actualidad. Se examinan los beneficios y consecuencias socioeconómicos y humanos de dicha legislación. Además, se presenta un análisis comparativo, tanto desde la perspectiva cultural como legislativa, para agregar contexto global a los cambios legislativos y judiciales pertinentes.

Palabras clave: los derechos de las mujeres, legislación, internacional, judicial.

\section{REFLECTIONS ON THE LEGISLATIVE \\ AND JUDICIAL EVOLUTION OF WOMEN'S RIGHTS IN SPAIN: FROM THE SECOND REPUBLIC TO THE PRESENT}

\begin{abstract}
This paper delivers a detailed analysis of the key legislative and judicial developments regarding women's rights in Spain from the Second Republic to the present. The socioeconomic and human benefits and consequences of said legislation are examined. Furthermore, a comparative analysis, from both cultural and legislative perspectives, is presented to add global context to the pertinent legislative and judicial changes.

KEYwORDS: women's rights, legislation, international, judicial.
\end{abstract}




\section{LA DESIGUALDAD JURÍDICA DE LA MUJER EN EL DERECHO ESPAÑOL TRAS EL FIN DE LA GUERRA CIVIL}

\subsection{INTRODUCCIÓN}

El punto de partida, para un preciso análisis del objeto de estudio y de su evolución, desde el final de la experiencia republicana hasta el final de la segunda década del régimen franquista, los años cincuenta del siglo $\mathrm{xx}$, debe ser doble: de una parte, la visión sucinta de la situación jurídica de la mujer durante la Segunda República, tanto desde el punto de vista constitucional como del legislativo; y de otra parte, la descripción y análisis de las transformaciones que vinieron como consecuencia de la guerra civil y la llegada de un nuevo régimen político introductor de un planteamiento específico, peculiar pero completamente discriminatorio, sobre los derechos de la mujer.

Ahora bien, de lo que no cabe duda es de que, vista la normativa de la época, la situación jurídica de la mujer, que sufrió una pérdida de derechos en el tránsito de régimen político desde la República hasta la dictadura del general Franco, puede definirse al menos como perjudicial tanto desde la restricción objetiva de sus derechos (también los de los hombres aunque, como se verá, en menor medida) como desde el mantenimiento de la mujer en un papel de inferioridad y sujeción con respecto al hombre. Tanto una como otra circunstancia deben ser vistas de todas formas teniendo en cuenta una doble consideración: el régimen franquista fue limitador de derechos para todas las personas, y no solo para las mujeres, al tratarse de un régimen autoritario y no democrático y poco o nada contemplativo en materia de derechos (si se hace la referencia principalmente a los llamados derechos políticos en su versión de derechos fundamentales y libertades públicas); y, además, fue especialmente severo en cuanto a la situación de la mujer en todos los ámbitos de su vida, y no solo el jurídico, resultando de todo punto significativo esto en el mundo de las normas, pues las que se dictaron fueron muy claras al limitar sus derechos y, en el caso de la mujer casada, al fijar con absoluta precisión su sometimiento jurídico al marido.

No cabe duda de que la instauración de un nuevo sistema político y constitucional en 1931, con el fin de la vigencia de un régimen político constitucionalmente monárquico por otro constitucionalmente republicano, alteró, como en tantos otros aspectos de la vida espańola de la época, el campo de los derechos de las mujeres. Es cierto que en esos momentos estaba anclada en España, como en los países del entorno, una tradición de discriminación contra la que había empezado a lucharse en los países de los dos bordes del Atlántico Norte a lo largo de las primeras décadas del siglo $\mathrm{xx}$, si bien es cierto que, en buena parte de los casos, la igualdad se quedó en el plano político, al concederse en varias de esas naciones a las mujeres los derechos de sufragio activo y pasivo (véase como ejemplo la enmienda XIX a la Consti- 
tución estadounidense, que aprobó el voto femenino en $1920^{1}$ ), pero sin que realmente se acometiera una verdadera equiparación de derechos en todos los ámbitos de la vida, tarea que con toda seguridad vino frenada por los acontecimientos que desembocaron en la Segunda Guerra Mundial, y que pospusieron las tareas legislativas de verdadera igualdad hasta la década de los sesenta.

Instaurada la República, habiendo tomado el poder, mediante elecciones, unos nuevos grupos políticos de corte más progresista, se acometió rápidamente, previo el correspondiente y necesario proceso electoral, la redacción de una nueva Constitución, a finales del propio año 1931. No había duda respecto de las mujeres y sus derechos: la Segunda República abogaba claramente por la igualdad y el fin de las discriminaciones de todo tipo, por lo que se promovió el fin de las restricciones de toda clase por razón de sexo. La declaración de principios en relación con la tónica de actuación general del nuevo régimen político va a ser la disposición incluida en la Constitución republicana en su artículo 25, que, rompiendo una arraigada tradición histórica y abriendo un nuevo camino, prohibió que el sexo sirviera de fundamento de cualquier privilegio jurídico («No pueden ser fundamentos de privilegio jurídico: la naturaleza, la filiación, el sexo, la clase social, la riqueza, las ideas políticas ni las creencias religiosas»).

A partir de ahí, la primera determinación tomada por la Segunda República que afectaba directamente, por el radical seguimiento de la idea de igualdad, a la situación jurídico-privada de la mujer (en este caso, y en parte, también a la del hombre) vino de la mano de la propia Constitución de 1931, que, en relación con el diseño constitucional del matrimonio, dispuso en su art. 43 tanto que «el matrimonio se funda en la igualdad de derechos para ambos sexos» como que «el matrimonio podrá disolverse por mutuo disenso o a petición de cualquiera de los cónyuges, con alegación en este caso de justa causa $»^{2}$. Y como derivación de esta proclama constitucional, se procedió más tarde a la aprobación tanto de la Ley de matrimonio civil de 28 de junio de 1932 como a la de la anterior Ley de divorcio de 2 de marzo del mismo año. En cuanto a la primera, es importante destacar que, además de ser terminante en cuanto a que no admitía más que la forma civil de matrimonio, dispuso que la celebración del matrimonio se sujetara al artículo 100 del Código civil, pero sin la lectura del artículo 57, que disponía la obediencia de la mujer al marido, lo que debió entenderse como una derogación tácita. Y, por otra parte, la Ley de divorcio, que procedió a su regulación desde el más absoluto respeto a la igualdad de los cónyuges en todo momento, dispuso ya en su artículo 1 que el divorcio decretado por sentencia firme de los Tribunales civiles disuelve el matrimonio cualquiera que

1 «The right of citizens of the United States to vote shall not be denied or abridged by the United States or by any State on account of sex. Congress shall have power to enforce this article by appropriate legislation».

2 Además, en el propio artículo 43 se establecía que «... Los padres tienen para con los hijos habidos fuera del matrimonio los mismos deberes que respecto de los nacidos en él... No podrá consignarse declaración alguna sobre la legitimidad o ilegitimidad de los nacimientos, ni sobre el estado civil de los padres, en las actas de inscripción, ni en filiación alguna». 
sea la forma de su celebración, además de permitir a los cónyuges contraer nuevo matrimonio con otras personas.

La segunda determinación presente en el texto constitucional fue la inclusión del derecho a voto verdaderamente universal al permitirse los derechos de sufragio femenino. Esto rompía la tradición (española, pero también de la generalidad de los países, más o menos en los mismos tiempos) de la omisión de referencia alguna expresa en los textos políticos de la época a la idea de igualdad política y de representatividad de los hombres y de las mujeres, lo que suponía un verdadero freno a la progresiva extensión del principio democrático típico de finales del siglo xix y de la primera mitad del siglo xx, pero siempre carente de la presencia femenina en el ejercicio del derecho a la participación política. Tras una, ya suficientemente estudiada en innumerables trabajos publicados, disputa por los constituyentes, especialmente por parte de las mujeres constituyentes (curiosamente, tras la llegada del nuevo régimen el nuevo gobierno provisional declaró elegibles a las mujeres por Decreto de 8 de mayo de 1931, tratándose de un hito histórico poco valorado), se aprobó el artículo 36, que reconoció «los mismos derechos electorales» para los ciudadanos de uno y otro sexo mayores de 23 años.

Por último, la Constitución, en su artículo 46, hizo otra referencia específica a las mujeres, esta vez en materia laboral, al disponer que la legislación social regularía «el trabajo de las mujeres y de los jóvenes, y especialmente la protección de la maternidad».

En definitiva, que la Segunda República apostó sin lugar a duda alguna por la no discriminación por razón de sexo en todos los ámbitos jurídicos, aunque las declaraciones constitucionales, en algún caso concreto como el de la situación jurídica de la mujer casada, no se vieron acompañadas de la necesaria y conveniente reforma de la legislación pertinente, en este caso el Código civil, que siguió manteniendo en su articulado las disposiciones relativas al papel predominante del marido y secundario de la esposa. Pudo deberse en todo caso a la difícil vida política del régimen republicano y a su final abrupto.

Terminado el sistema republicano, y establecido el régimen dictatorial, a cuyo frente se situó el general Franco, no cabe duda de que los avances en materia de derechos de la mujer sufrieron un violento frenazo y un posterior retroceso. Se puede afirmar que la peculiar declaración de derechos -y de deberes- de la dictadura franquista se estableció en una norma dictada unos años después de la guerra civil, y recién acabada la Segunda Guerra Mundial, tal vez por ser ese momento el de asentamiento (y tranquilidad) del régimen, visto el panorama en que había quedado Europa, y estando Espańa necesitada de un sistema de normas políticas que sustituyese la norma suprema habitual de todos los países del entorno europeo, una Constitución. No se optó por una Constitución, ni en el sentido formal ni en el sentido material, sino por un conjunto de leyes supremas del sistema político, que llegó a ser conocido como Leyes Fundamentales del Estado ${ }^{3}$. Esa norma, la llamada a ser

\footnotetext{
3 Serían, con el paso del tiempo y con pretensiones de estabilidad, las siguientes: Ley de principios fundamentales del Movimiento Nacional, Fuero de los Españoles, Fuero del Trabajo, Ley
} 
la declaración de derechos y deberes de los ciudadanos, es el Fuero de los Españoles, aprobado el 17 de julio de 1945 (se modificó por la Ley Orgánica del Estado de 10 de enero de 1967), que era una verdadera síntesis de muchos de los principios políticos del nuevo régimen, pero también una explicación de su idea de la sociedad que se quería instaurar en Espańa en esos momentos y de construcción de un modelo social definitivo. Y de ahí que, además de relacionar los deberes y derechos, se haga un diseño sociopolítico que encierra una fuerte carga ideológica extremadamente autoritaria, aunque el texto se salpique de proclamaciones de derechos que a la larga van a quedar como papel mojado, como las referencias a la libertad o a la igualdad.

Por esta razón vale la pena hacer algunas referencias a este texto, casi siempre olvidado en los estudios jurídicos sobre la época, y especialmente en los de los derechos de las mujeres, sin que deba olvidarse que estuvo vigente hasta el comienzo de la transición democrática de finales de los años setenta del siglo xx. La lectura del Fuero, que, como se dijo, pretendió ser un compendio de los derechos y de los deberes de los ciudadanos españoles, pero propio de un sistema férreamente autocrático, lleva rápidamente a la conclusión de que la propia denominación no implicaba, aunque lo pareciera, una exclusión de la mujer. La expresión «españoles» no se refiere solo a los hombres españoles, aunque el texto, además del título de la norma, hable continuamente de hombre, o de padres, pues se refiere a todos. Ahora bien, si se lee la norma en el contexto de la época, está claro que algunos de esos derechos, en la práctica, iban a ser ejercidos, por lo menos en los tiempos en que se dictó, únicamente por hombres; pero también los deberes, como el servir a la patria con las armas. Es decir, que da la sensación de que la norma no se planteó nada en este sentido, ni pretendió ser discriminatoria; era una declaración de derechos y deberes, y ya se vería quiénes ejercerían los unos y a quiénes obligarían los otros. En definitiva, que era una norma para todos, para el conjunto de la ciudadanía, pero estaba claro, por la configuración social de la época, que de aplicación preferentemente masculina, para lo bueno y para lo no tan bueno. Sería ilógico decir que no se refiere a las mujeres, puesto que, por ejemplo, regula el concepto de familia de la época, al tiempo que establece la obligación, a todos, de participar de la fe católica.

El Fuero de los Españoles comienza en su primer artículo con la proclamación general, que inspira todo el texto (o que debía hacerlo) del respeto a la dignidad, a la libertad y a la integridad del hombre como «titular de deberes y derechos», y continúa en el tercero declarando la «igualdad de derechos de todos los españoles, sin preferencia de clase ni acepción de personas", y aquí siempre debe suponerse que no hizo una referencia expresa a la discriminación por sexo porque se creía que no la había, ni el Fuero se había dictado solo para los hombres. Hay otros dos artículos que son especialmente relevantes a los efectos de este estudio, a falta de un precepto específico que hable de las mujeres, que como ya se puede deducir no se incluyó por considerarse innecesario, dado que se partía teóricamente de una ausencia de discriminación

constitutiva de las Cortes, Ley de Referéndum, Ley Orgánica del Estado y Ley de sucesión a la Jefatura del Estado. 
a este respecto (al margen de lo que fuera la realidad de la situación social y jurídica de la mujer). El artículo 22 regula la familia y el matrimonio, siendo un buen espejo de las ideas del régimen al respecto, incluidas las religiosas del catolicismo extremo. De una parte, en su primer párrafo, declara que el Estado reconoce y ampara a la familia como institución natural y fundamental de la sociedad, con derechos y deberes anteriores y superiores a toda ley humana positiva, mientras que en el segundo, con redacción categórica, regula el matrimonio, de una parte excluyendo cualquier forma de contraerlo que no sea la canónica, y de otra parte estableciendo la indisolubilidad del mismo, cuando señala que «el matrimonio será uno e indivisible». Por último, el artículo 23 se dedica a la descendencia familiar, estableciendo que «los padres están obligados a alimentar, educar e instruir a sus hijos». En definitiva, que este Fuero de los Españoles, dictado en los primeros años del régimen político franquista, ya ofrecía una perfecta delimitación de la situación de la mujer: no hay aparentemente discriminación alguna, el Fuero no lo hace, sino que coloca a cada persona en su lugar, al margen de que esto sea, sin duda alguna, una absoluta discriminación, que, como se verá, discurría por las sendas de lo fáctico y de lo jurídico.

\subsection{LOS DERECHOS DE LAS MUJERES EN LAS NORMAS JURÍDICAS DE LA ÉPOCA}

Las modificaciones jurídicas empezaron muy pronto: se dictan en plena guerra civil algunas disposiciones que eran un mero anuncio de una política bien trenzada de discriminación, y de lo que habría de venir. Se trata de la Ley de 5 de marzo de 1938, que ordenó la suspensión de los pleitos de divorcio (se derogó definitivamente la anterior Ley de divorcio de 1932 por nueva Ley de 23 de septiembre de 1939), y una semana más tarde, el día 12, la Ley que derogó la normativa anterior de matrimonio civil y concedió plena eficacia a los matrimonios contraídos en forma canónica, dado que aquel estaba «en pugna violenta con la conciencia nacional».

Dejando al margen estas normas referidas, el análisis del ordenamiento jurídico de las dos primeras décadas de régimen franquista lleva rápidamente a la conclusión de que lo que lo caracteriza desde este punto de vista es que ignora a la mujer y esta forma de ignorancia deriva de normas específicas o de normas generales que regulan de forma diferenciada a la mujer, y que no es producto precisamente de una conciencia de igualdad y de que no se regula nada porque nada hay que decir, sino que no se regula nada porque hay un statu quo de discriminación fáctica que no hace falta trasladarlo a la normativa. Esta circunstancia, por cierto, es la tónica de las grandes declaraciones de derechos de la historia contemporánea mundial hasta la primera mitad del siglo xx, que hablan en general pero que se interpreta que solo hablan de los hombres. Se quiere decir con esto que, en general, no hay normas que se refieran a la mujer (salvo las relativas a la mujer no emancipada o a la mujer casada en el Código civil), y todo ello al margen de que había una realidad social de absoluta diferenciación entre hombres y mujeres desde todos los puntos de vista, como se observa, a modo de ejemplo, en el papel de la mujer en la enseńanza, o en la religión, o como ama de casa, o su formación específica para su papel a cargo de la llamada Sección Femenina. 
La dictadura no suprimió el principal derecho político de una sociedad contemporánea, el derecho que otorga la posibilidad de participar en los órganos de gobierno de esa sociedad y de dirigirlos, el derecho de elegir a los representantes o ser elegido representante de la sociedad; en definitiva, el derecho de sufragio activo y pasivo. Fue un logro de la Segunda República el sufragio verdaderamente universal al incluirse en su Constitución el derecho al voto para hombres y mujeres. Pues bien, el régimen franquista no lo suprimió, no eliminó el derecho al voto de las mujeres; lo que hizo fue desnaturalizar hasta tal punto el derecho al sufragio, de todos, de hombres y mujeres, que hace que no se pueda hablar de idea de representatividad, de participación o de democracia. Es, por cierto, una obsesión de las dictaduras contemporáneas de los más variados signos buscar una especie de legitimación política mediante la convocatoria continua de procesos electorales o procesos de referéndum, con la idea de que sus ciudadanos puedan expresar su opinión, pero estos procesos alcanzan tal grado de intervencionismo del poder, y de manipulación de las voluntades de decisión, que esa pretensión de legitimidad resulta tan falseada como ridícula. A esta tendencia no escapó el régimen franquista, que sistemáticamente convocaba extrañas elecciones a las Cortes con una composición peculiar (únicamente a unos determinados procuradores en Cortes, elegidos por algunos sectores de la sociedad), alejada de cualquier parámetro democrático. La Ley Constitutiva de las Cortes 17 de julio de 1942, otra Ley Fundamental, no dispuso nada respecto del voto femenino, ni del masculino, aunque tenía un sistema electivo peculiar por sectores corporativos de la sociedad (familia, municipio y sindicato $)^{4}$, además de miembros natos y designados por el jefe del Estado, no prohibiendo en consecuencia el derecho de sufragio. Y ya la Ley de Referéndum de 22 de octubre de 1945, «por la que el jefe del Estado podrá someter a referéndum aquellas leyes que por su trascendencia lo aconseje o el interés público lo demande», como dice su propio nombre, dispuso en el artículo 2 que «el referéndum se llevará a cabo entre todos los hombres y mujeres de la Nación mayores de 21 ańos». Y, efectivamente, se celebraron algunos, y las mujeres pudieron votar, todos ellos con voto casi unánime a favor de las propuestas del régimen. Sirva de muestra que el 6 de julio de 1947 se celebró un referéndum para la aprobación popular de otra de las Leyes Fundamentales, en este caso la Ley de Sucesión a la Jefatura del Estado, y pudieron votar las mujeres, con los siguientes resultados oficiales, según los datos de la

${ }^{4}$ Posteriormente, la Ley Orgánica del Estado de 1967, aprobada precisamente en referéndum en el que votaron las mujeres (ya decía la Ley de Referéndum de 1945 que votan todos, hombres y mujeres), modificó la Ley Constitutiva de las Cortes de 1942 introduciendo un nuevo grupo de procuradores, en representación de las familias de España, junto a los que ya existían, y este cupo era elegido de forma popular con un peculiar cuerpo electoral. El artículo fue aprobado con el siguiente tenor literal: «f) dos representantes de la Familia por cada provincia, elegidos por quienes figuren en el censo electoral de cabezas de familia y mujeres casadas, en la forma que se establezca por ley». En definitiva, que en el referéndum votaban hombres y mujeres con el único requisito de la edad mínima, pero para elegir a sus procuradores en las Cortes solamente votaban hombres, en cuanto cabezas de familia, y mujeres casadas, en cuanto esposas de cabezas de familia. 
época: de un censo oficial de 16187992 electores, votaron 14454 426, de los que afirmativos fueron 12628983 , es decir, el 89,86 por ciento, mientras que los electores que votaron no fueron 643501 .

Al margen de esta aparente, pero muy engańosa, igualdad, al menos en el derecho al voto, lo cierto es que si se atiende al resto del ordenamiento se observa que las normas referidas a las mujeres no son numerosas, seguramente porque no hacía falta: la diferente situación jurídica de la mujer era un hecho, el producto de una realidad que se manifestaba en todos los órdenes de la vida, y, como ya se ha dicho, no hacía falta escribirlo en una norma.

Se trataría ahora de trazar un panorama de las normas que afectaban especialmente a la mujer, y la discriminaban, desde los distintos sectores del ordenamiento jurídico.

El Derecho penal de la época, cuyo texto regulador fundamental fue el Código penal de 1944, no pudo escapar de la visión genérica del régimen franquista de considerar a la mujer en una posición de inferioridad respecto del hombre y de la férrea moral correspondiente, lo que determina que lleve a cabo, por consiguiente, regulaciones específicas absolutamente atentatorias a la dignidad humana, la femenina en particular. Pero también ha de tenerse en cuenta que parte de esa normativa, como sucede, por ejemplo, con la regulación del uxoricidio y del adulterio, no fue invención de la época, sino más bien el rescate de una vieja tradición jurídica, pues son innumerables los textos de épocas anteriores que ofrecían tal regulación. La particularidad es el anacronismo que representaba al mantener vivas regulaciones similares a las que ya aparecían en los fueros medievales hispánicos en las Siete Partidas castellanas, tanto porque la Segunda República lo había eliminado como porque los tiempos y la sociedad habían cambiado, y lo que podía haber tenido cierta justificación en periodos remotos de la historia resultaba ahora de todo punto inadmisible al estar referido a una sociedad con cierto nivel de desarrollo desde cualquier punto de vista.

Por esta razón, la lectura, empezando con lo que hoy se puede llamar delitos sexuales, resulta sorprendente cuando, de una parte, parece que la víctima de la mayor parte de estos delitos (y especialmente del más grave, y más penado) solo puede ser la mujer, y, de otra parte, sorprende la lenidad de algunas penas, o mejor dicho la casi impunidad, como sucede con el adulterio cometido por el hombre, o con el uxoricidio u homicidio honoris causa.

Los artículos reguladores de la violación, el estupro y el rapto -el $429^{5}$, el $434^{6}$ y siguientes y el 440 y siguientes - solo admitían a la mujer como víctima en una especie de proteccionismo anómalo, mientras que el delito de abusos deshones-

\footnotetext{
de reclusión menor».

5 Art. 429 Código penal de 1944: «La violación de una mujer será castigada con la pena

${ }^{6}$ El art. 434 del Código penal de 1944 se refiere al estupro de una doncella mayor de doce años y menor de veintitrés, cometido por autoridad o cuidador.

7 Por ejemplo, el art. 440 del Código penal de 1994, que dispone que el rapto de una mujer ejecutado contra su voluntad y con miras deshonestas, será castigado con la pena de prisión mayor.
} 
tos en el art. $430^{8}$ se refiere a cualquier persona como víctima, al margen de su sexo. Al mismo tiempo, se introducía un mecanismo beneficioso para el condenado, pues para todos estos delitos (violación, abusos deshonestos, estupro y rapto) se preveía la posibilidad de la impunidad del autor o el no cumplimiento en el caso de condena, exigiéndose perdón y matrimonio, dado que el art. 443 señalaba que «el perdón expreso o presunto del ofendido, capaz legalmente, extingue la acción penal o la pena impuesta o en ejecución. El perdón no se presume sino por el matrimonio de la ofendida con el ofensor». E igualmente, un reflejo de la mentalidad de la época aparece con nitidez en el art. 444, al disponer que los reos de violación, estupro o rapto serán también condenados por vía de indemnización «a dotar a la ofendida, si fuere soltera o viuda», así como a «reconocer a la prole», y a «mantener a la prole».

La regulación del delito de adulterio también es significativa tanto por ser la continuidad, ahora parcialmente renovada, de una arraigada tradición histórico-jurídica, puesta nuevamente en vigor (en realidad, es una vuelta a una peculiar, y propia de tiempos pasados, especie de sistema de autotutela, aunque con pena irrisoria), como por la desigualdad de sexos ante una misma acción, que se calificaba como delictiva, pero que encubría una actitud despectiva ante la mujer. Basta la lectura del art. 428 a estos efectos: «El marido que, sorprendiendo en adulterio a su mujer, matare en el acto a los adúlteros o alguno de ellos, o les causare cualquiera de las lesiones graves, será castigado con la pena de destierro. Si les produjere lesiones de otra clase, quedará exento de pena. Estas reglas son aplicables, en análogas circunstancias, a los padres respecto de sus hijas menores de veintitrés años y sus corruptores, mientras aquellas vivieren en la casa paterna. El beneficio de este artículo no aprovecha a los que hubieren promovido, facilitado o consentido la prostitución de sus mujeres o hijas». En definitiva, que se podía imponer la pena de destierro como castigo a hechos tan notorios como un homicidio, o dos homicidios, o a las lesiones graves, o la exención de la responsabilidad criminal para las lesiones no graves.

Todo esto se acompañaba además con la regulación diferenciada del propio delito de adulterio en función del sexo de su autor, pues si lo cometía una mujer (casada), la previsión legal, que lo calificaba expresamente de adulterio, se encontraba en el art. 449, que lo castigaba con prisión menor (también para el que fuera condenado por tener las relaciones con ella) en una redacción peculiar, al decir que «el adulterio será castigado con la pena de prisión menor. Cometen adulterio la mujer casada que yace con varón que no es su marido, y el que yace con ella sabiendo que es casada, aunque después se declare nulo el matrimonio». Además, el Código añadía otra especie de autotutela cuando permitía que el marido engañado dispusiera a su criterio del cumplimiento efectivo de la pena por su esposa condenada, pues así lo señalaba el art. 451 al referir que el marido podrá en cualquier tiempo remitir la pena impuesta a su consorte (y la del adúltero). En cambio, el adulterio del marido no merecía tal nombre en el Código, si bien llevaba aparejada la misma

${ }^{8}$ Art. 430 del Código penal de 1944: «El que abusare deshonestamente de persona de uno u otro sexo [...] será castigada con la pena de prisión menor». 
pena, aunque a diferencia del de la esposa aquí se exigía cierta habitualidad y permanencia en la acción, de ahí que pareciera quedar impune la relación sexual esporádica; aparece en el art. 452, al decir que el marido que tuviere manceba dentro de la casa conyugal, o notoriamente fuera de ella, será castigado con prisión menor, mientras que introducía cierta dosis de benevolencia penológica en relación con la mujer, dado que la manceba sería castigada, a criterio judicial, con la misma pena de prisión menor o la de destierro.

En definitiva, y dejando de lado otros tipos penales significativos a estos efectos, como las estrictas y duramente penadas regulaciones del delito de aborto, o el uso de anticonceptivos, lo relevante es destacar que, desde el punto de vista jurídico-penal, la diferenciación por sexos existía, y que no era siempre con afán de protección, sino de auténtica discriminación con extrañas regulaciones en cuanto a sus posibles castigos que iban desde la exención de la responsabilidad criminal, la lenidad o la importancia del perdón.

Desde la perspectiva jurídico-laboral, el principal texto regulador de esta materia, el Fuero del Trabajo de 1938, también con la categoría de Ley Fundamental, y que es en verdad un compendio de la visión económica y social del nuevo régimen, ya hizo mención específica a la mujer, si bien mínima, pues se debió considerar que era irrelevante cualquier otra referencia en un mundo del trabajo que no estaba pensado para las mujeres. Así, en el art. 1 de la parte II se dice, cuando se habla de la defensa del trabajador, de su vida y de su trabajo, que el Estado «en especial, prohibirá el trabajo nocturno de las mujeres y niños, regulará el trabajo a domicilio y liberará a la mujer casada del taller y de la fábrica». A continuación, dictó el Decreto ley de 31 diciembre 1938 con ciertas medidas mitigadoras y, en concreto, prohibió el trabajo de la mujer casada a partir de determinados ingresos del marido. En el Reglamento Nacional del Trabajo de 27 de diciembre de 1939, se insistió en que la mujer debe cesar en su trabajo al casarse, y en las Regulaciones Laborales de 1942 se preceptuó que la mujer, al casarse, deja su puesto a cambio de la dote nupcial. Estas normas reflejaban la concepción ideológica del régimen, ya esbozadas en esta materia en el citado Fuero de Trabajo, y que eran la expresión de una realidad asentada sobre la idea de que el hombre trabaje para que sea el sostén económico de la familia, mientras que la vida de la mujer la conduce inevitablemente al matrimonio. Para terminar con estas citas legales, en la Ley de Contrato de Trabajo de 26 de enero de 1944 se prohibió a las mujeres el trabajo en determinadas tareas y se impuso un descanso mínimo de 12 horas entre jornadas.

Será la normativa civil la materia en que haya una regulación más densa y específica acerca de la mujer, reflejo de una concepción no solo meramente diferenciadora, sino discriminatoria. Son múltiples los preceptos del Código civil en este sentido, tanto en cuanto a la condición femenina en general como en cuanto a la situación jurídica de la mujer casada; se trata de los preceptos limitadores de su capacidad de obrar; de los actos que la mujer puede realizar con plena autonomía y de aquellos para los que es preceptiva la licencia marital. Además, de aquellos que contemplan el poder del marido en la casa familiar, en los actos de gestión y administración de sus intereses personales y económicos, entre otros. En general, esos artículos eran limitadores de derechos, al mismo tiempo que colocaban a la mujer 
en posición de inferioridad respecto del hombre, especialmente el marido, lo que se pone de manifiesto sobre todo con la licencia marital y la potestad doméstica de este.

Aunque la mayoría de edad estaba en los 23 años (art. 320 Código civil) a comienzos del régimen franquista, en virtud de lo dispuesto en la Ley de 13 de diciembre de 1943, a partir del 1 de enero de 1944 la mayoría de edad se adquiere a los 21 años. No obstante, las mujeres tenían otra importante limitación en el art. 321 (reformado por Ley de 20 de diciembre de 1952) ${ }^{9}$ al no poder abandonar el hogar familiar hasta los 25 años salvo que tuvieran licencia de sus padres, o para contraer matrimonio, o para entrar en una institución religiosa católica, o también cuando el padre o la madre hubieran contraído ulteriores nupcias o concurriera alguna otra causa que justificara la separación. Por otra parte, aparece otra limitación en el art. 22 del Código civil, que hasta la Ley de 22 julio de 1954, en que se modificó y desapareció, decía que «la mujer casada sigue la condición y nacionalidad de su marido», y que «la española que casare con extranjero podrá, disuelto el matrimonio, recobrar la nacionalidad espańola» con los requisitos del art. 21. La nueva Ley de 1954 en su redacción del art. 22 sí que estableció que «la mujer casada no podrá por sí sola adquirir voluntariamente otra nacionalidad, a menos que esté separada legalmente». A este debe añadirse la prohibición de ser testigos en los testamentos del art. 681.1 y la prohibición de ejercer cargos tutelares como ser tutores ni protutores que señala expresamente el art. 237.7, o ser vocales del consejo de familia (art. 294).

La situación jurídica de la mujer casada en la época, hasta las reformas parciales que llevó a cabo la Ley de 24 de abril de 1958, se podría analizar distinguiendo lo que podía hacer de lo que no podía hacer.

En cuanto a lo que podía realizar al menos formalmente, aparte de las facultades de disposición de los bienes parafernales y para los actos que se deriven del ejercicio de la potestad doméstica que le corresponda según el art. $62^{10}$, el art. 63 permite a la mujer casada otorgar testamento y ejercer los derechos y cumplir los deberes que le correspondan respecto a los hijos legítimos o naturales reconocidos que hubiera tenido con otro, y respecto a los bienes de los mismos. Según el segundo párrafo del art. 60, también puede defenderse en juicio criminal, y demandar y defenderse en los pleitos con su marido, o cuando hubiere obtenido habilitación conforme a lo que dispone la Ley de Enjuiciamiento Civil al respecto. Igualmente viene facultada por el art. 1413 para actuar cuando el marido disponga, administre o enajene

9 El artículo 321 originario del Código civil, vigente hasta la Ley de 20 de diciembre de 1952, decía los siguiente: «A pesar de lo dispuesto en el artículo anterior, las hijas de familia mayores de edad, pero menores de veinticinco ańos, no podrán dejar la casa paterna sin licencia del padre o de la madre en cuya compańía vivan, como no sea para tomar estado, o cuando el padre o la madre hayan contraído ulteriores bodas».

${ }^{10}$ Art. 62 del Código civil: «Son nulos los actos ejecutados por la mujer contra lo dispuesto en los anteriores artículos, salvo cuando se trate de cosas que por su naturaleza estén destinadas al consumo ordinario de la familia, en cuyo caso las compras hechas por la mujer serán válidas. Las compras de joyas, muebles y objetos preciosos, hechas sin licencia del marido, sólo se convalidarán cuando éste hubiese consentido a su mujer el uso y disfrute de tales objetos». 
los bienes conyugales de forma fraudulenta o contraria a la ley, causando perjuicio a la mujer ${ }^{11}$, y, por último, también puede exigir la constitución de hipoteca e inscripción de los bienes dotales, como dispone el art. 1352.

$Y$ en cuanto a lo que no estaba autorizada ni podía hacer se encuentra una variada gama de disposiciones limitadoras de la mujer casada en lo personal y en lo patrimonial. En lo personal destaca el deber de obediencia a su marido del art. $57^{12}$, o el deber de seguir a su marido donde quiera que fije su residencia, salvo, previa autorización judicial, "cuando el marido traslade su residencia a Ultramar o país extranjero", como dice el art. 58, o el ya citado deber de seguir la condición o nacionalidad de su marido del art. 22, derogado por la Ley de 22 de julio de 1954, o en la patria potestad la preferencia por el padre de su ejercicio sobre los hijos comunes del art. 154.1. Y en lo patrimonial, la potestad del marido domina igualmente sobre los bienes y el patrimonio de la mujer, y de ahí la prohibición de la administración de la sociedad conyugal del art. 59, por lo que le corresponde a este el derecho de administrar los bienes matrimoniales en el régimen económico de la sociedad de gananciales (art. 1412), y la dote (art. 1357), la instauración de la representación de la mujer por su marido y la prohibición de comparecer en juicio sin la licencia de este contemplada en el art. 60, o la prohibición del art. 61 de adquirir la mujer casada a título oneroso o lucrativo, enajenar sus bienes, ni obligarse sin licencia de su marido.

Esta fue la situación jurídica de la mujer tras la guerra civil, que, en realidad, era la misma desde la promulgación del Código civil en 1889 (con la salvedad de los ańos de tendencia igualadora de la Segunda República), reflejo de una concepción tanto de la superioridad del hombre como de una familia de dirección unitaria y jerarquizada por parte del marido. Sin embargo, durante la década de los cincuenta se empezó a considerar la conveniencia de adecuar la rígida normativa a la realidad socioeconómica y, sobre todo, a cierto cambio de mentalidades que veían absurdo el enorme campo discriminatorio de la mujer y la razonabilidad de introducir leves reformas de tendencia igualitaria. Así se hizo con las ya citadas Ley de 20 de diciembre de 1952 y Ley de 22 de julio de 1954, y se hará sobre todo con la Ley de 24 de abril de 1958, una de las grandes normas reformadoras de la época, dicho esto en el sentido del momento.

Esta Ley de 1958 pretendió la modificación de ciertos preceptos, tanto sobre la mujer en general como sobre la mujer casada en particular, pero con especial relevancia en cuanto a la ampliación de la capacidad de obrar -aunque en la norma se aluda, incorrectamente, a su capacidad jurídica- de la mujer y a la modificación del régimen económico de gananciales. "Aborda el problema de la capacidad jurídica de la mujer, que hace mucho tiempo se hallaba planteado [...]», «liberar a la mujer de ciertas limitaciones en su capacidad", así se manifiesta la propia Exposición de Motivos de la Ley. En síntesis, y en lo que aquí afecta, cabe destacar, en primer lugar, que se reformó el art. 237, sustituyendo la prohibición a la mujer en general

${ }^{11}$ La redacción originaria de este art. 1413 se modificó por la Ley de 24 de abril de 1958.

12 Art. 57 Código civil: «El marido debe proteger a la mujer, y ésta obedecer al marido». 
para ser tutora o protutora por la prohibición a la mujer casada sin licencia; se autorizó a la mujer para ser parte del consejo de familia; y, además, se eliminó la prohibición de ser testigo en los testamentos. En segundo lugar, se eliminó la diferencia de trato en el adulterio como causa de separación (que antes se establecía de forma claramente discriminatoria en el art. 105.1 y ahora pasa a contemplar el adulterio de cualquiera de los cónyuges); se estableció el mantenimiento de la patria potestad sobre sus hijos para la mujer que se casa de nuevo del art. 168. Y, en tercer lugar, la regulación del consentimiento de la mujer casada en la sociedad de gananciales para los actos dispositivos sobre bienes inmuebles o establecimientos mercantiles del art. 1413 del Código civil. En fin, como tímidos avances pueden ser calificadas estas reformas, siempre en el sentido de mejoras de la situación jurídica de la mujer.

Para terminar el estudio de este periodo, cabe mencionar, no tanto por su eficacia jurídica sino por ser un compendio de la ideología del régimen, una norma a la que se dio carácter también de Ley Fundamental del sistema franquista, tardía en el tiempo pero especialmente significativa por tratarse de un listado de los criterios que debían estar en la base del funcionamiento de la sociedad y el Estado. Esta Ley de Principios fundamentales del Movimiento Nacional de 1958 declaró que el Quinto Principio "funda la comunidad nacional en el hombre y en la familia», del que se puede predicar que es coherente con lo que ya llevaba insistiéndose en toda la normativa y en la concepción ideológica previa desde el final de la guerra civil, y sin que la utilización del término "hombre» se haga en un sentido exclusivamente masculino, al margen de la evidente superioridad masculina en lo fáctico del régimen. Igual coherencia puede observarse en el Sexto Principio, que sostiene que «las entidades naturales de la vida social (familia, municipio y sindicato) son las estructuras básicas de la comunidad nacional», y de ahí que fuera ese el modelo de la representación popular por tercios en las elecciones a Cortes. Sirva este texto para concluir que la situación jurídica de la mujer se estabilizó desde los primeros momentos del régimen, con las levísimas modificaciones, insuficientes e insustanciales de la citada Ley de 24 de abril de 1958 . Habrá que esperar a la posterior reforma del articulado del Código civil relativo a la mujer casada, operada por la relevante Ley 14/1975, de 2 de mayo, sobre reforma de determinados artículos del Código civil y del Código de comercio sobre la situación jurídica de la mujer casada y los derechos y deberes de los cónyuges, para que se pueda atisbar cierta cercanía de lo legal con lo social y con el ya inevitable fin de la discriminación, proceso que empezará su culminación con la Constitución de 1978.

\subsection{BREVE REFERENCIA A LA LEgISLACión SOBRE LA IGUALDAD JURÍdiCA DE LA MUJER EN LAS DOS ÚlTIMAS DÉCADAS DEL RÉGIMEN DE FraNCO}

Tras el paréntesis que para los derechos de la mujer supuso el franquismo, en las dos últimas décadas se produjo una tímida apertura en la que hay que destacar las siguientes leyes por la relativa importancia que tuvieron.

La primera es la Ley 56/1961, de 22 de Julio, sobre derechos politicos profesionales y de trabajo de la mujer, que, en su Preámbulo, después de decir que el prin- 
cipio de no discriminación por razón del sexo ni estado para ejercer los derechos políticos y profesionales y laborales ya está reconocido en el Fuero de los Españoles, añade que «la presente Ley no tiene por objeto otra finalidad que la de desarrollar y dar aplicación efectiva a tales principios, suprimiendo restricciones y discriminaciones basadas en situaciones sociológicas que pertenecen al pasado y que no se compaginan ni con la formación y capacidad de la mujer espańola ni con su promoción evidente a puestos y tareas de trabajo y de responsabilidad».

En el texto de esta Ley se afirma que el sexo por sí solo no puede implicar limitación y se establece la posibilidad de que pueda acceder a los distintos cuerpos y carreras de funcionarios de administraciones públicas y privadas. No obstante, esta posibilidad no es total, sino que, como el propio Preámbulo indica, esto es «sin otra cortapisa que la derivada de la existencia de trabajos que exigen esfuerzos desmesurados, respecto de los cuales, tanto la pura naturaleza como las convenciones internacionales sobre la materia suscritas por España, imponen la limitación». Y así, se puede observar que su articulado, tras reconocer que «la mujer puede participar en la elección y ser elegida para el desempeño de cualquier cargo público» y que "puede ser designada asimismo para el desempeño de cualquier cargo público del Estado, Administración Local y Organismos autónomos dependientes de uno y otra" (artículo segundo), o que "puede participar en oposiciones, concursos-oposiciones y cualesquiera otros sistemas para la provisión de plazas de cualesquiera Administraciones públicas. Asimismo, tendrá acceso a todos los grados de la enseñanza» (artículo tercero. Uno), a continuación, establece una serie de excepciones al estar vetado su ingreso en las armas y cuerpos de los Ejércitos de Tierra, Mar y Aire, salvo que por disposición especial expresa se conceda a la mujer el acceso a servicios especiales de los mismos; a la Administración de Justicia en los cargos de magistrados, jueces y fiscales, salvo en las jurisdicciones tutelar de menores y laboral; y tampoco puede ser personal titulado de la Marina Mercante, excepto las funciones sanitarias.

Como se puede comprobar, se trata de una muy tímida reforma, que, lejos de reconocer la igualdad total, mantiene una desigualdad para el ejercicio de determinadas profesiones.

Y si esto es así en lo referente al acceso a los diferentes cuerpos y carreras de funcionarios de Administraciones públicas, otro tanto se puede decir en lo referente a su capacidad para la contratación laboral, ya que si bien el artículo cuarto en su apartado uno establecía que «la mujer podrá celebrar toda clase de contratos de trabajo», y que «en las reglamentaciones de trabajo, convenios colectivos y reglamentos de empresa no se hará discriminación alguna en perjuicio del sexo", añadía un párrafo por el que se excluía a la mujer de determinados trabajos, al decir que «las disposiciones reglamentarias determinarán los trabajos que, por su carácter penoso, peligroso o insalubre, deben quedar exceptuados a la mujer».

Por otra parte, la preeminencia del hombre sobre la mujer queda patente en la necesidad que se establecía en la legislación de la autoridad marital para el ejercicio de los derechos recogidos en dicha Ley. Expresamente, el artículo quinto preveía que cuando se exigiera dicha autorización por la Ley, «deberá constar en forma expresa, y, si fuere denegada, la oposición o negativa del marido no será eficaz cuando 
se declare judicialmente que ha sido hecha de mala fe o con abuso de derecho». Es decir, si bien esta Ley supone un avance en los derechos de las mujeres, no deja de ser un avance muy limitado, pero al que no hay que privarle la importancia que tiene, dada la época en que fue dictada.

El 22 de julio de 1972 se dictó una nueva Ley ${ }^{13}$, que da una nueva redacción a los artículos 320 y 321 del Código civil, y fija la mayoría que edad a los veintiún ańos, otorgando, a partir de esta edad, capacidad para todos los actos de la vida civil, salvo las excepciones establecidas en casos especiales en el Código civil. De particular importancia es su artículo segundo, que deroga el número tercero del artículo 1880, y los artículos 1901 a 1919 de la Ley de Enjuiciamiento Civil. Se referían estos artículos a la posibilidad de decretar el depósito de la mujer soltera que «habiendo cumplido 20 ańos, trate de contraer matrimonio contra el consejo de sus padres y abuelos», y al procedimiento que se seguía para la constitución del depósito.

Por último, en el campo del derecho privado, la Ley 14/1975, de 2 de mayo de $1975^{14}$, reforma determinados artículos del Código civil y del Código de comercio sobre la situación jurídica de la mujer casada y los derechos y deberes de los cónyuges. Esta ley eliminó limitaciones a la capacidad de obrar de la mujer casada en las materias siguientes:

- En materia de nacionalidad, la mujer, hasta la aprobación de esta Ley, seguía la nacionalidad del marido. Tras esta reforma el matrimonio no dio lugar de manera automática a la adquisición, pérdida o recuperación de la nacionalidad española. Tanto la adquisición como la pérdida de la nacionalidad española tenían que ser voluntarias, y la recuperación, por la mujer casada, iba a seguir las reglas generales de toda recuperación de nacionalidad.

- En materia de capacidad de obrar de la mujer casada. Se suprimió la hasta entonces fórmula vigente por la que la protección era un atributo del marido, y la obediencia una obligación de la mujer. Esta discriminación dejó paso a un deber de protección mutuo y en interés de la familia, y a una participación igualitaria de la mujer en la determinación de la residencia de los cónyuges.

A partir de esta reforma, ninguno de los cónyuges ostentó la representación legal del otro, salvo que se confiriese voluntariamente. Se suprimió, por consiguiente, la necesidad de la licencia marital complementaria de la capacidad de la mujer para realizar actos o negocios jurídicos. Se respetó, eso sí, el régimen de consentimientos de ambos cónyuges que se necesitaba para determinados actos o negocios jurídicos.

${ }_{13}$ Ley 31/1972, de 22 de julio, Gaceta de Madrid núm. 36, 5 de febrero de 1881.

14 BOE núm. 107, de 5 de mayo de 1975. 
Durante la tramitación del procedimiento judicial de nulidad o separación del matrimonio, la mujer tuvo la administración de sus bienes. Y era el juez el que determinaba a quién correspondía la administración de los bienes gananciales.

Se eliminaron referencias a la no privación de la autoridad marital en los casos de prodigalidad, o a limitaciones especiales para la mujer menor en casos de tutela, que se encontraban recogidas en el Código civil. Asimismo, se suprimió la incapacidad que tenía la mujer casada para ser tutor o protutor, o la excusa para no serlo por el hecho de ser mujer.

En la cuestión relativa a la herencia, se eliminó la licencia marital para que pudiese ejercer el cargo de albacea la mujer casada, y para aceptar o repudiar las herencias; también se la facultó para pedir la partición de la herencia. Y en relación con el consentimiento en los contratos se suprimió la imposibilidad que tenía la mujer de prestar consentimiento, una imposibilidad que la colocaba en la misma situación que los locos o dementes y los sordomudos que no sepan escribir, o que los menores no emancipados.

En materia del régimen económico-matrimonial, se introdujo la posibilidad de modificarlo por voluntad de ambos cónyuges, a través de las capitulaciones matrimoniales.

Asimismo, en relación con los bienes privativos de la mujer o parafernales, la mujer, a partir de esta Ley, pudo disponer por sí sola de dichos bienes. Y una vez producida la separación judicial por sentencia firme, cualquiera de los cónyuges podía pedir la separación de bienes y ostentar la plena propiedad de aquellos que se le fueron adjudicados. En caso de que la separación se produjese por ausencia o interdicción, los bienes que se adjudicaran al ausente o interdicto los iba a administrar su representante o tutor. Por otra parte, la mujer administraba los bienes del matrimonio en caso de abandono de familia del marido. Además, cuando era la mujer la que administraba los bienes tenía idénticas facultades y responsabilidad que el marido cuando era este quien ejercía la administración.

Por último, el mismo criterio que utilizó la Ley para la reforma de la capacidad jurídica de la mujer casada en el Código civil se mantuvo para el Código de comercio, facilitando el ejercicio del comercio por ambos cónyuges y suprimiendo la antigua necesidad de la autorización marital.

\section{LA LEGISLACIÓN SOBRE LA IGUALDAD JURÍDICA DE LA MUJER TRAS LA MUERTE DE FRANCO}

\subsection{La Constitución española de 1978}

Tras la muerte de Franco, la regulación de los derechos de la mujer va a cambiar. El aislamiento internacional del régimen de Franco supuso un retroceso en comparación con lo que ocurría en otros países del entorno, en especial, en las democracias europeas occidentales. M. ${ }^{a}$ Carmen Sevilla González, en un reciente discurso de la apertura del curso 2019-2020 de la Universidad de La Laguna, afirma que si «el final de la contienda mundial significó en Occidente la conclusión de una 
etapa histórica significativa, es lo cierto que en España la situación política existente mantuvo la vigencia de unos criterios sociales, morales y políticos que resultaban obsoletos en el resto de Europa durante unas décadas más, hasta la llamada Transición democrática» ${ }^{15}$.

Fruto de la Transición democrática es la Constitución española, aprobada y promulgada el 27 de diciembre de 1978, que iba a cambiar el panorama de la igualdad de derechos de la mujer y ser el punto de arranque de las modificaciones legislativas que se iban a producir en los años posteriores. Dentro del articulado de la Constitución alguno expresamente se refiere a la igualdad jurídica de la mujer y el hombre. Es en estos artículos en los que se centra en esta sección, pero para una mejor comprensión de su texto es muy útil conocer alguna de las intervenciones parlamentarias, bien en su defensa, presentando enmiendas, o pidiendo su supresión. Es cierto que no nos podremos referir a todas estas intervenciones, y solo se recogerán aquellas que tienen más interés para el tema objeto de este estudio.

Publicado el Anteproyecto de Constitución el 5 de enero de $1978^{16}$, en su artículo 9, el apartado 1, establecía que los poderes públicos y los ciudadanos están sometidos a la Constitución y el ordenamiento jurídico "cuyos principios rectores son la libertad y la igualdad». Y su apartado 2 , decía que corresponde a los poderes públicos «promover las condiciones para que la libertad y la igualdad del individuo [...] sea real y efectiva [...]». El artículo 14 del Anteproyecto establecía la igualdad de todos los españoles ante la ley sin discriminación por razón del sexo. El artículo 23 apartado 2 incorporaba el derecho de todos los ciudadanos a acceder en condiciones de igualdad a las funciones y cargos públicos. El artículo 27, en su apartado 1, decía que «a partir de la edad núbil, el hombre y la mujer tienen derecho a contraer matrimonio y a crear y mantener, en igualdad de derechos, relaciones estables de familia». Y, por último, el artículo 30, apartado 2, en lo concerniente a la remuneración de los trabajadores, decía que en «ningún caso podrá hacerse discriminación por razón del sexo». Alguno de estos artículos, a medida que avanza la discusión, no solo varían en su contenido, sino también en su numeración.

Se inició el debate del Anteproyecto en la Comisión de Asuntos Constitucionales y Libertades Públicas del Congreso de los Diputados, que aprobó el artículo 9 , con 27 votos a favor y ninguna abstención ${ }^{17}$. Cuando se entró en la discusión del artículo 13 (que correspondía con el artículo 14 del Anteproyecto), la única diputada de la Comisión, María Teresa Revilla López, que formaba parte de la Unión de Centro Democrático (UCD), manifestó:

En este artículo que hemos votado afirmativamente, la mujer espańola adquiere, por fin la plenitud de derechos. Es verdad que la votación ha sido unánime, sin disidencias, como estaba reclamando nuestra sociedad. Pero las mujeres no vamos

15 Sevilla González, María Carmen, La igualdad juridica: un Proyecto inacabado (perspectiva desde la historia del derecho comparado), Universidad de La Laguna, septiembre 2019, p. 13.

16 Boletín Oficial de las Cortes, núm. 44 (en adelante BOC) 05/01/1978.

${ }^{17}$ Diario de Sesiones del Congreso (en adelante DSC), núm. 67, 16/05/1978, p. 2389. 
a dar las gracias por ello. Tampoco vamos a mirar hacia el pasado con amargura o con rencor. Ahora buscamos el futuro y en el futuro queremos simplemente poder ser, para ser lo que podamos. Queremos conservar nuestra feminidad, que es un atributo precioso de la humanidad y, al mismo tiempo, sin renunciar a poder ser protagonistas de nuestra propia vida y a participar en igualdad de esfuerzos y responsabilidades en el quehacer común.

Para ello necesitamos, además de la igualdad ante la ley, de una sociedad rica en posibilidades de vida y en formas de existencia, una sociedad flexible en sus sistemas de trabajo y educación, donde no sean incompatibles la maternidad y el trabajo, la vida familiar y la cultura. La mujer necesita de una sociedad flexible y plural, pero también la necesita el hombre, que empieza hoy a sentirse atrapado en un destino unidimensional.

Y para terminar, Señorías, que no se piense que la crisis de identidad de la mujer es solo un problema femenino, de mujeres, porque es un problema de la sociedad en su conjunto. La sociedad lo sufre y la soiedad se enriquecerá en sus soluciones ${ }^{18}$.

El texto del ahora artículo 14 fue aprobado por unanimidad.

El debate sobre el artículo 31, que correspondía al artículo 27 del Anteproyecto, da lugar a una importante discusión, pero esta se centra en el apartado 2, que era el que recogía en su texto el mandato para que el derecho civil regule las causas de separación y disolución del matrimonio. Fue el divorcio el caballo de batalla que llevó a algunos diputados del partido Alianza Popular, como Gregorio LópezBravo y de Castro y Licinio de la Fuente de la Fuente, a proponer su eliminación del texto constitucional y la no constitucionalización del divorcio ${ }^{19}$. Pero, en lo que a este estudio se refiere, el contenido del apartado 1 no dio lugar a debate alguno, y el texto completo del ahora artículo 31, con sus dos apartados, fue aprobado con solo dos votos en contra.

Al fin, tras publicarse el 1 de julio de 1978 el Dictamen de la Comisión de Asuntos Constitucionales y Libertades Públicas del Congreso ${ }^{20}$, fue presentado, el 5 de julio de 1978, al Congreso de los Diputados, el Dictamen del Proyecto de Ley de la Constitución española ${ }^{21}$. Estos artículos se integran en el Proyecto con los números 9, apartado 2; artículo 13; artículo 23; artículo 30, apartado 1; y artículo 32. Son de nuevo aprobados por amplia mayoría de votos, y de nuevo, como había ocurrido en las discusiones de la Comisión, el debate más amplio lo originó el apartado 2 del artículo 30, en lo referente a la constitucionalización del divorcio, que produjo de nuevo las enmiendas de López-Bravo y de Castro ${ }^{22}$, y del también diputado de Alianza Popular Pedro de Mendizabal Uriarte ${ }^{23}$.

${ }_{18}$ DSC, núm. 69, 18/05/1978, pp. 2445-2446.

19 DSC, núm. 72, 23/05/1978, en pp. 2614-2617, se puede leer la intervención de LópezBravo y De Castro y en pp. 2617-2620 la de De la Fuente de la Fuente.

${ }^{20}$ BOC, núm. 121, 01/07/1978.

${ }^{21}$ DSC, núm. 104, 05/07/1978.

22 DSC, núm. 107, 11/07/1978, pp. 4073-4077.

23 Ibidem, pp. 4077-4082. 
Enviado el Proyecto de Constitución al Senado, se inició el debate del Proyecto en la Comisión de Constitución el 18 de agosto de 1978. El texto del artículo 9 fue aprobado después de haber sido retiradas dos enmiendas que pretendían darle otro emplazamiento, o bien que figurase como artículo independiente.

Mayor discusión originó el artículo 13, que decía: «Los españoles son iguales ante la ley, sin discriminaciones por razón de nacimiento, de raza, de sexo, de religión, de opinión o por cualquier otras circunstancias personales o sociales». El senador Cela y Trulock presentó in voce una enmienda de carácter léxico, que finalmente fue aprobada, al entender que no se debe llamar circunstancias a las que son condiciones, como el sexo o la raza ${ }^{24}$. No fue aceptada, en cambio, la enmienda presentada por el senador Justino de Azcárate Florez, que pretendía reducir el texto del artículo al siguiente: «Los españoles son iguales ante la ley». Como le rebatió Luis Sánchez Agesta, la enumeración de las circunstancias y condiciones aparece en todas las declaraciones de derechos en general, porque van apareciendo aquellos derechos que son negados ${ }^{25}$. Uno de ellos lo había sido la igualdad por razón del sexo.

El apartado 1 del artículo 30, que decía: «A partir de la edad núbil, el hombre y la mujer tienen derecho a contraer matrimonio y a crear y mantener, en igualdad de derechos, relaciones estables de familia», sí que fue objeto de un amplio debate en la Comisión de Constitución del Senado. Además de la enmienda in voce del senador Cela y Trulock, que finalmente fue aprobada, consistente en sustituir la frase «a partir de la edad núbil», por «a partir de la edad fijada por la ley», existieron otras muchas que proponían modificar la redacción del texto del apartado $1^{26}$. De todas las intervenciones que se produjeron para defender sus enmiendas, se trae a estas páginas la de la senadora María Belén Landaburu Fernández, por el contenido de sus palabras. Manifiesta que había planteado una enmienda al apartado segundo del artículo 30, pero que después de haber escuchado el debate que había ocasionado el apartado primero, consideraba más adecuado plantearla en este

${ }^{24}$ Diario de Sesiones del Senado (en adelante DSS), Comisión de Constitución, núm. 43, 24/08/1978, p. 1799.

${ }^{25}$ Ibidem, p. 1800.

${ }^{26}$ DSS, Comisión de Constitución, núm. 45, 29/08/1978, así p. 2001, Xirinacs Damians, planteó una enmienda al apartado 1 del art. 30, que decía: «Toda persona tiene derechos al desarrollo de su afectividad y de su sexualidad, a contraer matrimonio, a crear relaciones estables de familia en libertad, en plena igualdad de derechos y deberes de los consortes entre sí y de ambos respecto a los hijos comunes y a decidir libremente el número de hijos que desea tener. A tal fin tiene derecho a acceder a la información necesaria y a los medios que permitan su ejercicio». El senador Villar Arregui, del Grupo Parlamentario de Progresistas y Socialistas Independientes (p. 2002), propone redactarlo así: «El matrimonio se origina en el consentimiento de los cónyuges y se funda en la igualdad de derechos y deberes recíprocos». El senador de UCD, Vicente Domínguez (pp. 2003-2004) propuso la siguiente redacción: «El hombre y la mujer, desde la edad que determine la legislación civil, tienen derecho a contraer matrimonio y crear, en igualdad de derechos, una familia». El también senador de UCD Antonio Fernández-Galiano Fernández (p. 2006), cree que o debe mencionarse la igualdad en el momento de contraer matrimonio, pues ya está en el artículo 13, pero sí debe hacerse «muy claramente cuando se trata de las relaciones entre los que ya son cónyuges, en el curso y en el acontecer de la vida matrimonial». 
con el objeto de que se recoja el principio de igualdad jurídica entre los cónyuges. La razón que esgrime es que la Comisión ha aprobado en el artículo 13 el principio de igualdad ante la ley sin discriminación, entre otras razones, por razón del sexo; que en el artículo 23 recoge el derecho a acceder en condiciones de igualdad a las funciones y cargos públicos. Es decir, se ha traducido constitucionalmente el principio de no discriminación en la esfera del Derecho público. Su pretensión -dicees "trasladar a la esfera del Derecho privado este principio de no discriminación, a la esfera del Derecho familiar, del Derecho matrimonial». Si no se hiciera así, se dejaría su regulación a una Ley Orgánica, «y podría ocurrir que no se hiciera con arreglo a este principio de igualdad jurídica, lo que supondría, de una parte, desconocer este principio que parece desprenderse el artículo 13 de la Constitución y, de otra, un evidente retroceso». Retroceso - dice- porque ya está reconocido en la Ley de 2 de mayo de 1975 por el que se modificaron diversos artículos del Código civil y del Código de comercio, y modificó las relaciones de los consortes dentro de la relación matrimonial, la nacionalidad de la mujer casada, los relativos a la fijación del domicilio conyugal, la supresión de la licencia marital, la capacidad de la mujer casada para el ejercicio del comercio, etc. La enmienda que defendió decía: "A partir de la edad núbil, el hombre y la mujer tienen derecho a contraer matrimonio basado en la igualdad jurídica entre los cónyuges ${ }^{27}$.

Una vez votadas las enmiendas, el texto definitivo del apartado 1 del artículo 30, que fue aprobado por la Comisión de Constitución del Senado, tenía la siguiente redacción: «El hombre y la mujer, a partir de la edad fijada por la ley, tienen derecho a contraer matrimonio basado en la igualdad jurídica de los cónyuges $\aleph^{28}$.

Aprobados también, tal como estaban redactados, el apartado 2 del artículo $23^{29}$ y el artículo $32^{30}$, la discusión del Proyecto de Constitución pasó al Pleno del Senado, que tuvo comienzo el 25 de septiembre de 1978.

Los artículos 9 y el antiguo artículo 13, que definitivamente pasa a ser el 14, fueron aprobados en la sesión del 26 de septiembre de $1978^{31}$. Mayor debate suscitó, en la sesión del 28 de septiembre de 1978, el artículo 32 -que corresponde al antiguo 30-, si bien centrado principalmente en el tema del divorcio. No obstante, no deja de haber alusiones a la igualdad jurídica del hombre y de la mujer, como la del senador Lluís Maria Xirinacs i Damians, pues, aunque la redacción del apartado 1 del artículo 32 le parecía claramente insuficiente, ya que «se consagra una vez más, como en otros textos constitucionales, la mentalidad clásica del matrimonio», reco-

27 Ibidem, Landaburu GonzÁlez, pp. 2004-2005.

${ }^{28}$ Ibidem, p. 2008.

${ }^{29}$ DSS, Comisión de Constitución, núm. 44, 25/08/1978.

30 DSS, Comisión de Constitución, núm. 45, 25/08/1978.

31 DSS, núm. 59, 26/09/1978, pp. 2951-2952, fue aprobado el apartado 2 del art. 9, por 137 votos a favor y 14 en contra, con 11 abstenciones; los apartados 1 y 3 por 152 votos a favor, ninguno en contra y 1 abstención. En p. 2962 consta que fue aprobado por 190 votos a favor y ninguno en contra, sin abstenciones. 
nocía que «hay la mejora, la corrección importante de la igualdad de los cónyuges ${ }^{32}$ ». El artículo 32 fue aprobado en dicha sesión ${ }^{33}$. Asimismo, en la misma sesión, después de rechazar otra enmienda presentada por el senador Xirinacs i Damians, rebatida por el senador de UCD Julio Nieves Borrego, fue aprobado el artículo $35^{34}$.

Tras las modificaciones propuestas por el Pleno del Senado, el 28 de octubre de 1978 fue publicado el Dictamen de la Comisión Mixta del Congreso y Senado sobre el Proyecto de Constitución, en el que los artículos 9 apartado 2, 14, 23 apartado 2, 32 apartado 1 y 35 apartado 1 tenían la redacción que finalmente fue aprobada por ambas Cámaras el 31 de octubre de 1978, y que formaran parte del texto definitivo de la Constitución española sancionada y publicada el 27 de diciembre de 1978. Esta redacción es la siguiente:

\section{Artículo 9.2}

Corresponde a los poderes públicos promover las condiciones para que la libertad y la igualdad del individuo y de los grupos en que se integra sean reales y efectivas; remover los obstáculos que impidan o dificulten su plenitud y facilitar la participación de todos los ciudadanos en la vida política, económica, cultural y social.

Artículo 14

Los espańoles son iguales ante la ley, sin que pueda prevalecer discriminación alguna por razón de nacimiento, raza, sexo, religión, opinión o cualquier otra condición o circunstancia personal o social.

Artículo 23.2

Asimismo, tienen derecho a acceder en condiciones de igualdad a las funciones y cargos públicos, con los requisitos que señalen las leyes.

Artículo 32.1

El hombre y la mujer tienen derecho a contraer matrimonio con plena igualdad jurídica.

32 DSS, núm. 61, 28/09/1978, p. 3049. Xirinacs Damians creía en un modelo de relaciones más amplio que el incluido en el texto del proyecto constitucional. Así, decía (p. 3050), refiriéndose a la enmienda que defendía: «Creo que el texto recuerda un poco los Estados Unidos a finales del siglo pasado con sus clásicas reivindicaciones feministas de primera hora. La enmienda recoge la vida que bulle al final del siglo presente de la forma más concisa posible. Aparte del matrimonio, reconoce que toda persona tiene derecho al desarrollo de su afectividad o de su sexualidad, a contraer matrimonio, a crear relaciones estables de familia en libertad, en plena igualdad de derechos y deberes de los consortes entre sí y de ambos con respecto de los hijos comunes y a decidir libremente el número de hijos que deseen tener. A tal fin tienen derecho a acceder a la información necesaria y a los medios que permitan su ejercicio». Su enmienda fue rechazada.

33 Ibidem, p. 3054, fue aprobado el artículo 32 por 160 votos a favor y 1 en contra, con 9 abstenciones.

34 Ibidem, p. 3059, fue aprobado el artículo 35 por 148 votos a favor, ninguno en contra y 3 abstenciones. 


\section{Artículo 35.1}

Todos los españoles tienen el deber de trabajar y el derecho al trabajo, a la libre elección de profesión u oficio, a la promoción a través del trabajo y a una remuneración suficiente para satisfacer sus necesidades y las de su familia, sin que en ningún caso pueda hacerse discriminación por razón de sexo.

\subsection{LA LEGISLACIÓN SOBRE LA IGUALDAD JURÍDICA DE LA MUJER EN LAS TRES ÚL- TIMAS DÉCADAS DEL SIGLO XX}

Tras la aprobación de la Constitución española de 1978, se sucedieron diferentes leyes en el terreno de la igualdad jurídica de las mujeres y del hombre que afectaron a diferentes campos del Derecho: al Derecho civil, al penal -en este campo incluso antes de ser aprobada la Constitución-, al laboral. A esta legislación nos referiremos ahora, antes de abordar las leyes transversales que fueron aprobadas a comienzos del siglo Xxi y que afectaron a todos los campos del Derecho.

Si se comienza con la década de los setenta, las primeras reformas tuvieron lugar en el campo del Derecho penal, muy sensible a los cambios políticos. De ahí que, incluso antes de aprobarse la Constitución, ya se produjeron en la normativa penal modificaciones para adaptar su legislación a la nueva situación política. Es preciso tener en cuenta que el Código penal que estaba vigente era del año 1944, en el que estaba penado el adulterio y el amancebamiento, que fue despenalizado por la Ley 22/1978, de 26 de mayo, sobre despenalización del adulterio y del amancebamiento ${ }^{35}$. En efecto, el artículo 449 del Código penal de 1944 decía: «El adulterio será castigado con la pena de prisión menor. Cometen adulterio la mujer casada que yace con varón que no sea su marido, y el que yace con ella, sabiendo que es casada, aunque después se declare nulo el matrimonio». Y el artículo 452: «El marido que tuviere manceba dentro de la casa conyugal, o notoriamente fuera de ella, será castigado con prisión menor. La manceba será castigada con la misma pena o con la de destierro...». Por lo demás, en los artículos 450 y 451 se exigía querella del marido agraviado contra "ambos culpables», que no podía entablar en caso de que lo hubiere consentido, y asimismo preveía el perdón y la remisión de la pena impuesta por parte del marido. La ley 22/1978, en su artículo 1, deroga los artículos 449 a 452 del Código penal y suprime el capítulo de dicho Código que llevaba como rúbrica la expresión "Adulterio». También son derogados los artículos del Código civil que tenían su causa en el adulterio, como la incapacidad de suceder, o ser una causa de desheredación.

Tampoco se puede pasar por alto la Ley 45/1978, de 7 de octubre ${ }^{36}$, que despenaliza la divulgación y propaganda de anticonceptivos, que en el Código penal de 1944 estaban penados en el párrafo primero y en los apartados 4 y 5 de su artículo

35 BOE núm. 128, de 30 de mayo de 1978.

36 BOE núm. 243, de 11 de octubre de 1978. 
416. Por otra parte, la Ley 46/1978, de 7 de octubre ${ }^{37}$, modifica los delitos de estupro y de rapto, y desaparecieron exigencias del antiguo Código penal, como, en el delito de estupro, la de que la víctima fuese "doncella» o tuviese "acreditada honestidad», o «ser mujer honesta». En tanto que en el de rapto se va a penalizar atentar contra la libertad sexual de la mujer, en lugar del hecho de actuar «con miras deshonestas", como se recogía en el Código penal de 1944.

En la década de los ochenta hubo mucha actividad legislativa que afectó a la situación jurídica de la mujer. Cronológicamente, la primera Ley fue, en el campo del Derecho laboral, el Estatuto de los Trabajadores. En efecto, el artículo 35.1 de la Constitución española prohibió la discriminación por razón del sexo, y con la aprobación de la Ley 4/1980, de 10 de marzo de 1980 ${ }^{38}$, del Estatuto de los Trabajadores, este mandato se vio reflejado en alguno de sus artículos. Concretamente en los siguientes: en el apartado 2 del artículo 4, que, entre otros extremos, decía: «En la relación de trabajo, los trabajadores tienen derecho: [...] c) A no ser discriminados para el empleo o una vez empleados, por razones de sexo...». En el artículo 17, bajo el epígrafe "No discriminación en las relaciones laborales», en su apartado 1, estableció que «se entenderán nulos y sin efectos los preceptos reglamentarios, las cláusulas de los convenios colectivos, los pactos individuales y las decisiones unilaterales del empresario que contengan discriminaciones desfavorables por razón de edad o cuando contengan discriminaciones favorables o adversas en el empleo, así como en materia de retribuciones, jornadas y demás condiciones de trabajo, por circunstancias de sexo...». Y en el artículo 28, bajo el epígrafe "Igualdad de remuneración por razón de sexo», al decir que "el empresario está obligado a pagar por la prestación de un trabajo igual el mismo salario, tanto por salario base como por los complementos salariales, sin discriminación alguna por razón de sexo». No obstante, como mantiene Lousada Arochena, presentaba defectos importantes, como el de hacer una declaración de igualdad solo salarial y no por trabajo de igual valor, o mantener vestigios paternalistas como la titularidad femenina del permiso de lactancia ${ }^{39}$.

También en el campo del Derecho civil se produjeron modificaciones legislativas de importancia en la década de los ochenta. La primera Ley que se dictó es la Ley 11/1981, de 13 de mayo, de modificación del Código civil en materia de filiación, patria potestad y régimen económico del matrimonio ${ }^{40}$. Era una Ley que protegía a los hijos, y proporcionaba al hijo matrimonial, no matrimonial y adoptivo el mismo tratamiento. Suprimió la terminología anterior de hijo legítimo, ilegitimo o legitimado, pasando a denominarse matrimonial o no matrimonial. A partir de esta Ley la verdad biológica para determinar la paternidad adquirió la máxima relevancia (arts. 127-130 tras la reforma), frente a la prohibición que existía en la anterior

\footnotetext{
37 Ibidem.

38 BOE núm. 64, de 14 de marzo de 1980.

39 Lousada Arochena, José Fernando, El derecho fundamental a la igualdad efectiva de hombres y mujeres, Valencia, 2014, p. 92.

40 Publicada en BOE núm. 119, de 19 de mayo de 1981.
} 
redacción del Código civil, lo que constituyó un avance para la defensa de los intereses de los hijos y madres. En orden a determinar la filiación, el reconocimiento tuvo lugar sin límites en relación con los hijos (antes solo cabía reconocer a los hijos naturales), aunque primando siempre interés del reconocido ${ }^{41}$. Por otra parte, la patria potestad, a partir de esta Ley, se ejercitará conjuntamente por ambos progenitores, o por uno de ellos con el consentimiento del otro. También modificó el régimen económico del matrimonio, que se iba a estipular en capitulaciones matrimoniales, y en su defecto, la gestión y disposición de los bienes gananciales iba a corresponder, conjuntamente, a los cónyuges.

A pesar de no ser una ley que específicamente se refirió a la igualdad jurídica de mujeres y hombres, por su importancia, hay que destacar la que fue cronológicamente segunda reforma sustancial del Código civil tras la vigencia de la Constitución española, la Ley 30/1981, de 7 de julio, por la que se modifica la regulación del matrimonio en el Código civil y se determina el procedimiento a seguir en las causas de nulidad, separación y divorcio ${ }^{42}$. Uno de los artículos de la Constitución que había producido en 1978 mayor debate parlamentario fue el apartado 2 del artículo 32, porque decían los parlamentarios que se oponían a que fuese integrado en la Constitución, que su redacción equivalía a constitucionalizar el divorcio. La importancia de esta Ley se puede ver en las palabras del que era entonces ministro de Justicia, Fernández Ordoñez, en la presentación del Proyecto de Ley, que, entre otras cosas, dijo:

España lleva muchos siglos, desde la Cédula de 1564 de Felipe II, con la realidad invariable de una tradición de indisolubilidad, que atraviesa, incluso, nuestro proceso constitucional desde la Constitución de Cádiz y recorre todo el siglo xIX hasta llegar a la primera, y hasta ahora única, formulación del divorcio vincular en el artículo 43 de la Constitución de 1931.

Como consecuencia de esta declaración de la Constitución de 1931 se promulgaron las leyes de 1932 de matrimonio civil y de divorcio. Poco más tarde, en plena guerra civil, el 12 de mayo de 1938 queda derogada esta legislación: se permitió la revocación de los divorcios dictados con arreglo a ella y se declararon nulos todos los matrimonios civiles contraídos durante la guerra.

Hoy, casi cincuenta años después, reiniciamos el esfuerzo de incorporar a nuestro derecho una figura jurídica con cerca de dos siglos de antigüedad, desde la revolución liberal ${ }^{43}$.

${ }^{41}$ Sobre el alcance de esta reforma en la filiación vid. Moreno-Chinchilla Jiménez, Laura, «La filiación no matrimonial antes y después de 1981», Universidad Pontificia de Comillas, Madrid, abril 2014.

42 Publicada en $B O E$ núm. 172, de 20 de julio de 1981.

43 DSC, núm. 150, 17/03/1981. Dictamen de la Comisión de Justicia, sobre el Proyecto de Ley que modifica la regulación del matrimonio en el Código civil y se determina el procedimiento en las causas de nulidad, separación, divorcio. Fernández Ordoñez, p. 9397. En el debate se presentaron numerosas enmiendas, alguna a la totalidad y por diferentes razones, en unas ocasiones pidieron la devolución del Proyecto de Ley al Gobierno, ya que el divorcio no se debía establecer en la legislación, vid. Díaz-Pines Muñoz, de UCD, pp. 9402-9408, o Piñar López, de Fuerza Nueva 
A partir de esta Ley el divorcio ha estado vigente en España -con modificaciones parciales- ininterrumpidamente, hasta la actualidad.

En materia de Derecho de familia continuó la adaptación de la legislación a las normas constitucionales con la Ley 13/1983, de 24 de octubre, que reformó el Código civil en materia de tutela ${ }^{44}$. Es preciso tener en cuenta que en la redacción del Código civil anterior a esta reforma -a pesar de las modificaciones realizadas por la Ley 14/1975, de 2 de mayo de 1975-, se daba preferencia al padre para ejercer el cargo de tutor, con expresiones tales como que la tutela corresponde «al padre y en su caso a la madre» (artículos 220 y 227 de la redacción anterior). Asimismo, tenían preferencia para formar el Consejo de Familia las personas «que el padre, o la madre, en su caso, hubiesen designado...». (art. 294 redacción anterior), estableciendo una preferencia para integrarlo del «varón a la mujer» (art. 295 redacción anterior). Con la Ley de 24 de octubre de 1983 desaparecieron dichas expresiones y desigualdades estableciendo la igualdad de las mujeres y los hombres en materia de tutela.

También tuvo importancia la Ley 21/1987, de 11 de noviembre, por la que se modificaron determinados artículos del Código civil y de la Ley de Enjuiciamiento Civil en materia de adopción ${ }^{45}$. No solo porque se intentó que prevaleciera el interés del adoptado, sino porque, en lo que a este estudio se refiere, se modificó el artículo 9 del Código civil sobre derecho internacional privado, eliminando, como dice en su preámbulo, «discriminaciones hirientes contra la mujer». En efecto, modificó los apartados 4 y 5 del artículo 9 del Código civil. El apartado 4 decía: «Las relaciones paterno-filiales se regirán por la ley nacional del padre y en defecto de éste, o si sólo hubiere sido reconocida o declarada la maternidad, por la de la madre». El apartado 5, en su párrafo segundo, «en la adopción por marido y mujer a falta de ley nacional común, se aplicará la del marido al tiempo de la adopción». Estas discriminaciones contra la mujer desaparecieron en la nueva redacción. No obstante, quedó sin modificar el apartado 2 del artículo 9, que establecía: «Las relaciones personales entre los cónyuges se regirán por su última ley nacional común durante el matrimonio y, en su defecto, por la ley nacional del marido al tiempo de la celebración», y el apartado 3, que remitía las relaciones patrimoniales entre los cónyuges, en caso de que no existiesen capitulaciones, a la ley que regía las relaciones personales. Por lo que la discriminación contra la mujer continuó perviviendo.

En década de los ochenta también se continuaron las reformas en el campo del Derecho penal. La Ley Orgánica 8/1983, de 25 de junio ${ }^{46}$, modificó la condena para los reos de violación, estupro o rapto, pues en el Código penal de 1944 la indemnización consistía en "dotar a la ofendida, si fuera soltera o viuda», y tras la

(pp. 9410-9415). En otras ocasiones por considerar insuficiente la regulación que contenía el Proyecto, vid. Pi-Suñer Cuberta, de Esquerra Republicana de Catalunya (pp. 9398-9402), o Bandrés Molet, de Euskadiko Esquerra (pp. 9409-9410).

${ }_{44}$ Publicada en $B O E$ núm. 256, de 26 de octubre de 1983.

45 Publicada en $B O E$ núm. 275, de 17 de noviembre de 1987.

46 BOE núm. 152, de 27 de junio de 1983. 
reforma, se sustituyó por la de «indemnizar a la persona ofendida». Además, en esta reforma, como decía su Exposición de Motivos, «de acuerdo con la igualdad de la posición de los cónyuges, legalmente reconocida ya fuera del derecho penal, se suscribe la supresión a la mención de la autoridad marital, presente en varios preceptos». Y dentro de las faltas contra las personas, los apartados 2 y 3 del artículo 583, referentes a los maltratos del marido y la mujer, quedaron refundidos en un único apartado que decía: «El que maltratare a su cónyuge o hijos menores de palabra o de obra aunque no les causare lesiones de las comprendidas en el párrafo anterior».

La Ley Orgánica 3/1989, de 21 de junio ${ }^{47}$, supuso una nueva modificación del Código Penal. Sustituyó la expresión delitos «contra la honestidad» por la de delitos "contra la libertad sexual», al ser este el auténtico bien jurídico atacado. Incluyó en los delitos de violación, además del vaginal, el rectal y bucal, pudiendo ser sujetos pasivos tanto las mujeres como los hombres. Por otra parte, como decía la Exposición de Motivos de esta Ley, se incorporó al Código penal «una nueva modalidad de abandono de familia, consistente en el impago de prestaciones económicas establecidas por convenio o resolución judicial, en los casos de procesos matrimoniales».

Se entra, por fin, en la década de los noventa, en la que continuó la actividad legislativa en los tres campos del Derecho. En el Derecho civil, la Ley 11/1990, de 15 de octubre, sobre reforma del Código civil, en aplicación del principio de no discriminación por razón de sexo ${ }^{48}$, como decía en su Preámbulo, «pretende eliminar las discriminaciones que por razón de sexo aún perduran en la legislación civil y perfeccionar el desarrollo normativo del principio constitucional de igualdad». Las modificaciones más importantes que introdujo esta Ley en materia de igualdad de los derechos de la mujer con las siguientes:

Dio una nueva redacción de los apartados 2, 3, 5 y 8 del artículo 9 del Código civil, para dejar zanjada, de una vez por todas, la desigualdad que continuaba existiendo en Derecho internacional privado.

En relación con la adquisición de la vecindad civil, eliminó el apartado 4 del artículo 14, que decía que "la mujer casada seguirá la condición del marido, y los hijos no emancipados, la de su padre, y, en defecto de éste, la de su madre».

En materia de sucesiones fue modificado un párrafo del artículo 1066 del Código civil, que en la redacción anterior establecía que «cuando el mismo título comprenda varias fincas adjudicadas a diversos coherederos, o una sola que se haya dividido entre dos o más, el título quedará en poder del mayor interesado en la finca o fincas, y se facilitarán a las otras copias fehacientes, a costa del caudal hereditario. Si el interés fuere igual, el título se entregará al varón, y, habiendo más de uno, al de mayor edad». El último párrafo se sustituyó por otro que decía: «Si el interés fuere igual, el título se entregará, a falta de acuerdo, a quien por suerte corresponda».

47 BOE núm. 148, de 22 de junio de 1989.

48 Publicada en $B O E$ núm. 250, de 18 de octubre de 1990. 
Dentro del consentimiento de los contratos, se modificó el tercer párrafo del artículo 1267 del Código civil, que decía: «Para calificar la intimidación debe atenderse a la edad, al sexo y a la condición de la persona». Y fue sustituido por otro con la siguiente redacción: «Para calificar la intimidación debe atenderse a la edad y a la condición de la persona».

Por lo demás, la disposición transitoria de esta Ley estableció que «la mujer casada que hubiere perdido su vecindad por seguir la condición del marido, podrá recuperarla declarándolo así ante el Registro Civil en el plazo de un año a partir de la publicación de esta Ley».

En el Derecho laboral, se produjeron una serie de reformas que tuvieron lugar a partir del año 1994. La primera de ellas tuvo lugar con la aprobación de la Ley de 11/1994 de mayo de 1994, que modificó determinados artículos del Estatuto de los Trabajadores ${ }^{49}$. En concreto, el artículo 28 quedó redactado de la siguiente manera: «El empresario está obligado a pagar por la prestación de un trabajo de igual valor el mismo salario, tanto por salario base como por los complementos salariales, sin discriminación alguna por razón de sexo». Del mismo año es la Ley 42/1994, de 30 de diciembre ${ }^{50}$, en la que, como decía en su Preámbulo, «se configura como contingencia específica, desligada de la incapacidad laboral transitoria, la de maternidad $\aleph^{51}$.

Una nueva modificación del Estatuto de los Trabajadores tuvo lugar con la Ley 4/1995, de 23 de marzo, de regulación del permiso parental y por maternidad $^{52}$. Así, en la Exposición de Motivos de esta Ley, se decía que uno de los ámbitos en que la discriminación del género se seguía produciendo era el correspondiente al del acceso al mercado laboral en la selección de personal. Una de estas situaciones que condicionaban esta situación era la derivaba de «la posible baja o circunstancia tipificadas actualmente como incapacidad laboral transitoria del permiso por maternidad, así como la posibilidad de que se solicite la excedencia durante un período no superior a tres ańos para poder atender al cuidado de cada hijo indistintamente por parte del padre o bien de la madre». Para mitigar este problema, extendió el periodo de excedencia forzosa a todo el periodo de excedencia establecido por la Ley para el cuidado de los hijos, y como contrapartida los puestos que quedaban vacantes eran cubiertos por nuevos contratos en las condiciones que se establecía dicha ley ${ }^{53}$.

Otros aspectos que afectaban al trabajo de las mujeres también fueron objeto de una regulación a partir de esta década de los años noventa. Así la Ley 31/1995,

49 BOE núm. 122, de 23 de mayo de 1994.

50 BOE núm. 313, de 31 de diciembre de 1994.

51 Introduce en el Título II de la Ley General de la Seguridad Social un nuevo Capítulo IV bis que lleva por rúbrica «Maternidad» y que abarca los artículos 133, bis, 133, ter, 133 quater y 133 quinquies.

52 BOE núm. 71, de 24 de marzo de 1995.

53 Con tal finalidad esta Ley modificó el apartado 3 del artículo 46 del Estatuto de los Trabajadores. 
de 8 de noviembre, de Prevención de Riesgos Laborales, en su artículo 26, estableció que, en caso de que las condiciones de trabajo supusiesen un riesgo para la seguridad o la salud de las trabajadoras en situación de embarazo o parto reciente, el empresario estaba obligado a adoptar las medidas necesarias para evitar la exposición a dicho riesgo, a través de una adaptación de las condiciones o del tiempo de trabajo; y cuando esta adaptación no fuese posible, la trabajadora debía desempeñar un puesto de trabajo o función diferente y compatible con su estado. Y la Ley 39/1999, de 5 de noviembre, para promover la conciliación de la vida familiar y laboral de las personas trabajadoras ${ }^{54}$, creó la prestación de riesgo durante el embarazo, con la finalidad de proteger la salud de la mujer trabajadora embarazada ${ }^{55}$.

No se puede terminar este recorrido por la década de los noventa sin hablar de una Ley, la Ley Orgánica 5/1995, de 22 de mayo, del Tribunal del Jurado ${ }^{56}$, que, aunque es procesal, supuso la reintroducción del jurado en España, y, a diferencia de lo que ocurrió el anterior periodo en que estuvo vigente, supuso la participación de la mujer en el jurado en igualdad de condiciones que el hombre. Es cierto que la Ley republicana que modificó la Ley del Jurado entonces vigente dio paso, por primera vez en la historia de España, a que la mujer formase parte del jurado, y supuso un avance respecto a la legislación anterior, pero insuficiente, puesto que era muy limitada, ya que solo tenía lugar en los llamados crímenes pasionales, es decir, en los delitos de parricidio, asesinato, homicidio o lesiones, en los que el móvil pasional fuera el amor, los celos, la fidelidad o cualquier otro aspecto de las relaciones sexuales, y en los que fuesen de distinto sexo agresores y víctimas. Suspendido el jurado por un Decreto de la Junta de Defensa Nacional de 8 de septiembre de 1936, no volvió a establecerse en España hasta esta Ley de 22 de mayo de 1995, de ahí la importancia que tiene no solo por el restablecimiento del jurado, sino también para la igualdad jurídica de la mujer.

\section{LA LEGISLACIÓN SOBRE LA IGUALDAD JURÍDICA DE LA MUJER DEL SIGLO XXI}

\subsection{LAS LEYES TRANSVERSALES DE LA PRIMERA DÉCADA DEL SIGLO XXI}

Nos referiremos por último a dos leyes que se pueden calificar de transversales. Con esta denominación se hace referencia, como dice Lousada Arochena, a las leyes que sitúan el acento en la revisión de todo el ordenamiento jurídico, y «al afectar a todo el ordenamiento jurídico, son leyes que, rompiendo la técnica jurídica tradicional de ordenación atendiendo a la materia, contemplan las más diversas

${ }^{54} B O E$ núm. 266, de 06/11/1999.

55 Vid. Nuñez Fiaño, María del Carmen, El mutualismo judicial: acción protectora de la MUGEJU, Capitulo V. Acción protectora. Tesis doctoral inédita, defendida en octubre de 2019 en la Facultad de Derecho de la Universidad de A Coruña.

56 BOE núm. 122, de 23 de mayo de 1995. 
materias hasta potencialmente todas las abordables por el ordenamiento jurídico ${ }^{57}$. Las leyes a las que nos referimos en esta parte son la Ley Orgánica 1/2004, de 28 de diciembre, de Medidas de Protección Integral contra la Violencia de Género, y la Ley Orgánica 3/2007, de 22 de marzo, para la igualdad efectiva de mujeres y hombres.

a) Ley Orgánica 1/2004, de 28 de diciembre, de Medidas de Protección Integral contra la Violencia de Género.

El 7 de octubre de 2004, en el Congreso de los Diputados, el entonces ministro de Trabajo y Asuntos Sociales, Caldera Sánchez-Capitán, presentó y defendió el dictamen del Proyecto de Ley de Violencia de Género, con el objetivo básico de erradicar la violencia que se proyectaba hacia las mujeres. Para ello, como manifestó en su presentación del proyecto de ley, «articula nuevos organismos: Delegación del Gobierno contra la Violencia sobre la Mujer, Observatorio Nacional de Violencia sobre la Mujer». Y establecía medidas de protección integral en diversos campos: «En el ámbito de la publicidad y de los medios de comunicación», en el de «la educación incidiendo, en la primera etapa educativa y también en la enseñanza de adultos», en «la sensibilización y formación del personal sanitario para mejorar la atención y rehabilitación de la víctima», en «la especialización y coordinación de las Fuerzas y Cuerpos de Seguridad del Estado, policías locales, administraciones públicas», en «el reconocimiento de derechos laborales y de Seguridad Social», en "la sanción y persecución del agresor», y en "la especialización de juzgados» ${ }^{58}$. De la intervención de los diputados de los distintos grupos políticos en el debate sobre el Proyecto de Ley, pese a las enmiendas presentadas en aspectos tales como el de atribuir mayores competencias a las comunidades autónomas -principalmente defendidas por los grupos nacionalistas-, o que se extendiera la educación a la universitaria, o, en fin, un mayor alcance de la asistencia social y mayor dotación presupuestaria, y a pesar de la crítica general de la excesiva rapidez en la elaboración del Proyecto de Ley, se puede sacar la conclusión de que hay una coincidencia en la necesidad de esta Ley, y en definitiva, en dar un voto favorable a ella ${ }^{59}$. Tras el trámite parlamentario del Senado, el Proyecto de Ley fue remitido de nuevo al Congreso de los Diputados, y en la sesión del 22 de diciembre de 2004, después de una nueva intervención de los diputados de los distintos grupos parlamentarios, en las que mostraron su satisfacción de que muchas de sus enmiendas fueran incorporadas al texto del Proyecto de

57 Lousada Arochena, J. Fernando, op. cit., pp. 78-79.

58 Caldera Sánchez-Capitán, DSC, núm. 39, 7/10/2004, pp. 1703-1705.

59 Las enmiendas se pueden consultar en el DSC, núm. 39, 7/10/2004, pp. 1705-1720, en el que se pueden ver las intervenciones de los diputados Barkos Berruezo (Nafarroa Bai), Lasagabaster Olazabal (Eusko Alkartasuna), Fernández Dávila (Bloque Nacionalista Galego), Rodríguez Rodríguez (Coalición Canaria), García SuÁrez (Izquierda Verde-Izquierda Unida-Iniciativa per Catalunya Verds), Uría Etxebarría Grupo Parlamentario Vasco (EAJ-PNV), Bonàs Pahisa (Esquerra Republicana), Pigem i Palmés (Grupo Catalán de Convergència i Unió), Camarero Benítez (Grupo Parlamentario Popular). 
Ley en el Congreso y el Senado, fue votado y aprobado por unanimidad con 325 votos de todos los diputados concurrentes ${ }^{60}$.

La definitiva Ley Orgánica 1/2004, de 28 de diciembre, de Medidas de Protección Integral contra la Violencia de Género ${ }^{61}$, con alguna diferencia en la denominación de los nuevos organismos, que pasaron a ser denominados Delegación Especial del Gobierno contra la Violencia sobre la Mujer y Observatorio Estatal de Violencia sobre la Mujer, y la incorporación de alguna de las enmiendas presentadas, tales como la ampliación de la educación en igualdad de género a las universidades, dar mayores competencias a las comunidades autónomas o la ampliación de la asistencia social y medidas de protección a las víctimas, establece, en su articulado, en líneas generales los principios y las medidas de protección integral que había defendido el ministro de Trabajo y Asuntos Sociales en la presentación del dictamen del Proyecto de Ley.

La otra Ley transversal a la que nos referimos es la Ley Orgánica 3/2007, de 22 de marzo, para la igualdad efectiva de mujeres y hombres ${ }^{62}$. Fue presentado el Dictamen de la Comisión legislativa del Proyecto de Ley el 21 de diciembre de 2006 en el Congreso de los Diputados. Su presentación fue también llevada a cabo por el entonces ministro de Trabajo y Asuntos Sociales, Caldera Sánchez-Capitán, que la calificó como una ley transversal e integral, ya que «la ley expande el derecho a la igualdad entre mujeres y hombres en todo orden vital y se adentra en todos los ámbitos, sean públicos o privados». Y señaló los principales objetivos de la Ley, de los que destacó estos: lograr que las mujeres puedan acceder a los órganos de dirección de las empresas en las mismas condiciones que los hombres; prestar especial protección a las mujeres inmigrantes; lograr la igualdad en el mundo de la cultura, en el acceso a las nuevas tecnologías y a la sociedad de la información; extender la protección de la ley a las trabajadoras autónomas; flexibilizar el acceso a la prestación de maternidad; mejorar la conciliación de la vida personal, familiar y laboral; elevar la duración del permiso de paternidad; lograr una composición equilibrada de las listas electorales ${ }^{63}$. Los distintos grupos políticos, si bien en sus intervenciones formularon algunas enmiendas puntuales, mostraron un consenso a las líneas generales de la Ley, con la excepción del Grupo Parlamentario del Partido Popular, que, a través de su diputada Camarero Benítez, manifestó su voto en contra del Proyecto, tanto por imponer los planes de igualdad, defendiendo en su lugar una política de incentivos, como por el sistema de cuotas electorales que trata de imponer, además de añadir otros motivos, por ejemplo, entendía la diputada del Partido Popular que se debía ampliar el permiso de paternidad ${ }^{64}$.

${ }^{60}$ En DSC, núm. 61, 22/12/2004, pp. 2928-2942 se pueden leer las intervenciones y la votación final.

${ }^{61} B O E$ núm. 313, de 29/12/2004.

${ }^{62}$ BOE núm. 71, de 23/03/2007.

63 Caldera Sánchez-Capitán, DSC, núm. 225, 21/12/2006, pp. 11457-11459.

${ }^{64}$ Así, tanto Barkos Berruez (Nafarroa Bai), Fernández Dávila (Bloque Nacionalista Galego), Mardones Sevilla (Coalición Canaria), García Suárez (Izquierda Unida-Iniciativa per 
Remitida la Ley al Senado, se debatió el Dictamen de la Comisión de Trabajo y Asuntos Sociales, el 7 de marzo de 2007. La defensa volvió a llevarse a cabo por Caldera Sánchez-Capitán, que de nuevo insistió en lo que había expuesto en el Congreso de los Diputados. En la discusión del Senado no dejó de haber alusiones a la oportunidad de la fecha, ya que el día siguiente, el 8 de marzo, era el Día Internacional de la Mujer. La tónica general fue la misma que en la otra Cámara. Así, los senadores de los grupos de izquierdas y nacionalistas, si bien defienden algunas enmiendas, entre otras, encaminadas a dotar de planes de igualdad a empresas de menos de 250 trabajadores, o a que la composición de las listas electorales fuese de 50-50 - caso de Izquierda Unida-, o bien a dar mayores competencias a los gobiernos autónomos, o a extender la protección a la mujer en el mundo rural -caso de grupos nacionalistas-, pero todos mostraron su disposición a dar su voto favorable al Proyecto de Ley. En tanto que las senadoras Fúnez de Gregorio y Campo Piñeiro, del Grupo Parlamentario del Partido Popular, mostraron su disconformidad con el Proyecto e insistieron en las enmiendas que habían presentado en el Congreso, llegando a interesar que se añadiesen nuevas prestaciones como, entre otras, por riesgo durante la lactancia, movilidad, creación de bonos para guarderías, incentivos para la paridad en las listas electorales, eliminación de lenguaje sexista. Enmiendas que llevaron a senadoras de otros grupos, como a Aleixandre Cerarol, de Convergència i Unió, a considerarlas irrefutables si no fuera por el coste económico, o a la senadora del Grupo Parlamentario del Partido Socialista Martínez García a calificarlas como un «más y más que pondría en peligro la Seguridad Social» ${ }^{65}$.

El Proyecto de Ley enmendado fue aprobado en el Senado y se convirtió en la Ley Orgánica 3/2007, de 22 de marzo, para la igualdad efectiva de mujeres y hombres, compuesta de un título preliminar, 8 títulos integrados por 78 artículos, 31 disposiciones adicionales, 11 disposiciones transitorias, una disposición derogatoria y 8 disposiciones finales. Tras una Exposición de Motivos en la que se afirma que la igualdad efectiva de mujeres y hombres es un principio jurídico universal, reconocido en las distintas convenciones internacionales (Naciones Unidas 1979, Nairobi 1985, Beijing 1995) y que incorpora las últimas Directivas de la Comunidad Europea sobre igualdad (2002/73/CE, 76/207/CEE, 2004/113/CEE), incluyó en una Ley Orgánica los principios, políticas, acciones, planes y derechos que fueron sacados a la luz en el debate parlamentario, encaminados a la igualdad efectiva de mujeres y hombres.

No se puede pasar por alto que, a finales de la primera década del siglo XXI, se promulgó la Ley Orgánica 2/2010, de 3 de marzo, de salud sexual y reproduc-

Catalunya Verds), Uría Etxebarría (EAJ-PNV), Oliva i Peña (Esquerra Republicana), Pigem i PALmÉs (Convergència i Unió), ibidem, pp. 11459-11469, formularon entre otras enmiendas referentes a las competencias de sus territorios, en materia de conciliación, acogimiento, o el caso de niños prematuros, pero mostraron su disposición a su voto a favor. La discordancia se produjo por la diputada del Grupo Parlamentario del Partido Popular señora Camarero Díaz pp. 1169-11472.

65 Todas estas intervenciones se pueden ver en el DSS, núm. 113, 07/03/2007, pp. 68966922. 
tiva y de la interrupción voluntaria del embarazo ${ }^{66}$. El Preámbulo de esta Ley dice que «la protección de este ámbito de autonomía personal tiene una singular significación para las mujeres, para quienes el embarazo y la maternidad son hechos que afectan profundamente a sus vidas en todos los sentidos». Añade que diversos textos internacionales han puesto de manifiesto la relación de la protección de los derechos de la mujer con la protección sexual y reproductiva, mencionado en particular, en el ámbito de la Naciones Unidas, el artículo 12 de la Resolución 34/180, de 18 de diciembre de 1979, que establece que los Estados Partes deberán adoptar las medidas adecuadas para eliminar la discriminación de la mujer con el hombre en el acceso a los servicios de atención médica, incluida la planificación familiar. Otro de los textos a los que alude es el reconocimiento que se hizo en la Plataforma de Acción de Beijing acordada en la IV Conferencia de Naciones Unidas sobre la mujer, celebrada en 1995, del derecho de las mujeres a tener el control y decidir libre y responsablemente sobre su sexualidad, incluida la salud sexual y reproductiva, libre de presiones, discriminación y violencia. Y, por último, menciona la Resolución 2001/2128 (INI) del Parlamento Europeo sobre salud sexual y reproductiva y los derechos asociados, en la que se constatan las enormes desigualdades entre las mujeres europeas en el acceso a los servicios de salud reproductiva, a la anticoncepción y a la interrupción voluntaria del embarazo en función de sus ingresos, niveles de renta o el país donde residen.

El articulado de la Ley va incorporando dichas declaraciones y medidas. Es de destacar que conforme al artículo 14 de la Ley, en un plazo de catorce semanas las mujeres tienen la posibilidad de tomar una decisión libre e informada sobre la interrupción del embarazo.

Excepcionalmente, el artículo 15 a) y b) permite interrumpir el embarazo por causas médicas siempre que no se superen las veintidós semanas de gestación, cuando «exista grave riesgo para la vida o la salud de la embarazada y así conste en un dictamen emitido con anterioridad a la intervención por un médico o médica especialista distinto del que la practique o dirija». O bien «siempre que exista riesgo de graves anomalías en el feto y así conste en un dictamen emitido con anterioridad a la intervención por dos médicos especialistas distintos del que la practique o dirija».

A partir de la veintidós semana siguiente a la gestación, se considera que el nasciturus ya tiene vida independiente. Desde esa fecha, en caso de existir riesgo para la salud de la mujer, entiende la Ley que lo adecuado es un parto inducido. Si bien establece el artículo 15 c) dos supuestos excepcionales de interrupción del embarazo cuando «se detecten anomalías fetales incompatibles con la vida», o "se detecte en el feto una enfermedad extremadamente grave e incurable en el momento del diagnóstico y así lo confirme un comité clínico».

No se puede terminar este epígrafe sin hacer una referencia a un Anteproyecto que ha iniciado su trámite parlamentario, el de Ley Orgánica de garantía inte-

${ }^{66} B O E$ núm. 55, de 04/03/2010. 
gral de libertad sexual, al que dio luz verde el 3 de marzo de 2020 el Consejo de Ministros, y que supone una reforma de los delitos sexuales del Código penal, no solo en lo que se refiere a las penas, sino también en el consentimiento de las víctimas, provocada por los últimos casos de delitos de esta naturaleza en los que se ha cuestionado el consentimiento de la víctima al no haber una negativa expresa a la agresión sexual, de ahí que sea conocida como la Ley del «sí es sí». No obstante, en el momento de escribir estas líneas, aún es un Anteproyecto de Ley.

\subsection{BREVE REFERENCIA A LA LEGISLACIÓN AUTONÓMICA SOBRE LA IGUALDAD DE LA MUJER}

No quedarían completas estas reflexiones sin hacer una mención, aunque sea breve, a la labor llevada a cabo por los legisladores autonómicos en las reformas de los distintos Estatutos de Autonomía, para llevar a cabo la igualdad jurídica de la mujer. Estas reformas van incorporando en su normativa artículos similares para garantizar la igualdad de mujeres y hombres, proteger a las mujeres de la violencia de género, al tiempo que atribuyen a las Comunidades Autónomas la competencia exclusiva en políticas de igualdad. En muchas de estas Comunidades Autónomas ya se encontraban vigentes leyes de igualdad de género y de protección contra la violencia de género cuando se aprobaron estas reformas; en otras, fueron aprobadas con posterioridad. Sin ánimo de ser exhaustivo pues la reforma que hace cada Estatuto de Autonomía en esta materia requiere un estudio independiente, nos vamos a referir muy brevemente a ellas.

En la Comunidad Valenciana ya se había promulgado una Ley para la Igualdad entre mujeres y hombres, el 2 de abril de 2003, cuando se llevó a cabo la reforma de su Estatuto de Autonomía ${ }^{67}$. El Estatuto de Autonomía de Valencia fue reformado en el año $2006^{68}$, y en su artículo 11 establece que «la Generalitat, conforme a la Carta de Derechos Sociales, velará en todo caso para que las mujeres y los hombres puedan participar plenamente en la vida laboral, social, familiar y política sin discriminaciones de ningún tipo y garantizará que lo hagan en igualdad de condiciones. A estos efectos se garantizará la compatibilidad de la vida familiar y laboral». Y otorga competencia exclusiva a la Generalitat, en su artículo 49.1.26a, para la "promoción de la mujer».

En Cataluña, con anterioridad a la reforma de su Estatuto, una Ley del 9 de abril de 2001 modificó el apartado 2 del artículo 63 de la Ley 13/89, de 14 de diciembre, para exigir que las propuestas de disposición de carácter general de la

${ }^{67}$ Ley 9/2003, de 2 de abril, para la igualdad entre mujeres y hombres. BOE núm. 110, de 8 de mayo de 2003 .

${ }^{68}$ Ley Orgánica 1/2006, de 10 de abril, de Reforma de la Ley Orgánica 5/1982, de 1 de julio, de Estatuto de Autonomía de la Comunidad Valenciana. BOE núm. 86, de 11 de abril de 2006. 
Administración de la Generalitat de Catalunya vayan acompañadas de una memoria que, entre otros aspectos, ha de valorar la perspectiva de la igualdad de género.

El Estatuto de Autonomía de Cataluña tras su reforma ${ }^{69}$, dentro del capítulo I, sobre los derechos y deberes del ámbito civil y social, dedica el artículo 19 a los derechos de las mujeres, y establece:

1. Todas las mujeres tienen derecho al libre desarrollo de su personalidad y capacidad personal, y a vivir con dignidad, seguridad y autonomía, libres de explotación, malos tratos y todo tipo de discriminación.

2. Las mujeres tienen derecho a participar en condiciones de igualdad de oportunidades con los hombres en todos los ámbitos públicos y privado.

Pero no se quedan ahí sus previsiones, pues en el artículo 41, bajo el enunciado Perspectiva de género, establece la obligación de los poderes públicos de garantizar «el cumplimiento del principio de igualdad de oportunidades entre mujeres y hombres en el acceso a la ocupación, la formación, la promoción profesional, las condiciones de trabajo, incluida la retribución, y en todas las demás situaciones», «que las mujeres no sean discriminadas por causa de embarazo o maternidad», «la transversalidad en la incorporación de la perspectiva de género y de las mujeres en todas las políticas públicas para conseguir la igualdad real y efectiva y la paridad entre mujeres y hombres", "que se haga frente de modo integral a todas las formas de violencia contra las mujeres y a los actos de carácter sexista y discriminatorio; deben fomentar el reconocimiento del papel de las mujeres en los ámbitos cultural, histórico, social y económico, y deben promover la participación de los grupos y las asociaciones de mujeres en la elaboración y evaluación de dichas políticas». Así como su deber de «reconocer y tener en cuenta el valor económico del trabajo de cuidado y atención en el ámbito doméstico y familiar en la fijación de sus políticas económicas y sociales» y de "velar para que la libre decisión de la mujer sea determinante en todos los casos que puedan afectar a su dignidad, integridad y bienestar físico y mental, en particular en lo que concierne al propio cuerpo y a su salud reproductiva y sexual».

Para terminar, otorga a la Generalitat, en el artículo 153, la competencia exclusiva en materia de políticas de género.

Como en la Comunidad Valenciana, en la Comunidad Autónoma de las Illes Balears, ya estaba vigente una Ley de Igualdad de derechos entre hombre y mujeres, la Ley de 26 de septiembre de $2006^{70}$, antes de la aprobación de su reforma estatutaria. Por su parte, el Estatuto de Autonomía de las Illes Balears ${ }^{71}$, en su art. 16.3, dentro del Título II, referido a los derechos, los deberes y las libertades de los

${ }^{69}$ Ley Orgánica 6/2006, de 19 de julio, de reforma del Estatuto de Autonomía de Cataluña. $B O E$ núm. 172 , de 20/07/2006.

${ }^{70}$ Ley 12/2006, de 20 de septiembre, para la mujer. BOE núm. 248, de 17 d octubre de 2006.

${ }^{71}$ Ley Orgánica 1/2007, de 28 de febrero, de reforma del Estatuto de Autonomía de las Illes Balears. BOE núm. 52, de 01/03/2007. 
ciudadanos de las Islas Baleares, entre los ámbitos en que deberá centrarse primordialmente la actuación de las Administraciones públicas de las Islas Baleares, se encuentra «la igualdad de derechos de hombres y mujeres en todos los ámbitos, en particular en materia de empleo y trabajo; la protección social contra la violencia, especialmente la violencia de género». Y el artículo 17, bajo el epígrafe de No discriminación por razón de sexo, establece, en sus dos primeros números:

1. Todas las mujeres y hombres tienen derecho al libre desarrollo de su personalidad y capacidad personal, y a vivir con dignidad, seguridad y autonomía.

2. Las Administraciones públicas, según la Carta de Derechos Sociales, velarán en todo caso para que las mujeres y los hombres puedan participar plenamente en la vida laboral, social, familiar y política sin discriminaciones de ningún tipo y garantizarán que lo hagan en igualdad de condiciones. A estos efectos se garantizará la conciliación de la vida familiar y laboral.

Otorgando a la Comunidad Autónoma, de la misma manera que los dos Estatutos anteriores, la competencia exclusiva en "políticas de género» (art. 30.17).

En el año 2007 se reforma el Estatuto de Autonomía de Andalucía ${ }^{72}$, y su artículo 14, dentro del Título dedicado a los Derechos sociales, deberes y políticas públicas, prohíbe "toda discriminación en el ejercicio de los derechos, el cumplimiento de los deberes y la prestación de los servicios contemplados en este Título, particularmente la ejercida por razón de sexo». Garantiza, en su artículo 15, la igualdad de oportunidades entre hombres y mujeres. Y establece, en su artículo 16, el derecho de las mujeres a una protección integral contra la violencia de género, que incluya medidas preventivas asistenciales y ayudas públicas.

Son principios rectores del Estatuto de Autonomía de Andalucía «la lucha contra el sexismo» (art. 37.2. ${ }^{\circ}$ ), y la "plena equiparación laboral entre hombres y mujeres» (art. 37. 11. ${ }^{\circ}$ ). Además, se atribuye la Comunidad Autónoma la competencia exclusiva en materias de política de género, que incluye, conforme dispone el artículo 73:

a) La promoción de la igualdad de hombres y mujeres en todos los ámbitos sociales, laborales, económicos o representativos.

Se atribuye expresamente a la Comunidad Autónoma la facultad de dictar normativas propias o de desarrollo en esta materia.

b) La planificación y ejecución de normas y planes en materia de políticas para la mujer, así como el establecimiento de acciones positivas para erradicar la discriminación por razón de sexo.

c) La promoción del asociacionismo de mujeres.

${ }^{72}$ Ley Orgánica 2/2007, de 19 de marzo, de reforma del Estatuto de Autonomía para Andalucía. $B O E$ núm.68, de 20 de marzo de 2007. 
En el procedimiento de elaboración de sus normas (leyes y disposiciones reglamentarias) «se tendrá en cuenta el impacto por razón de género del contenido de la mismas» (art. 114). Y establece que, en el nombramiento de los titulares de los órganos de gobierno de la Administración andaluza, una ley regulará el principio de presencia equilibrada de hombres y mujeres (art. 135).

En fechas posteriores a la aprobación de esta reforma, fueron aprobadas en Andalucía leyes de igualdad de género y de protección contra la violencia de género, ambas de fecha 26 de noviembre de $2007^{73}$.

En Aragón, la reforma de su Estatuto de Autonomía ${ }^{74}$, tras prescribir en el artículo 12 todo tipo de discriminación, recoge el derecho de acceder en condiciones de igualdad a la cultura, desarrollo de las capacidades creativas y disfrute del patrimonio cultural, a los servicios públicos de salud, a participar en los asuntos públicos y a unos servicios públicos de calidad (artículos 13 al 15).

Uno de los objetivos a los que deben orientar sus políticas los poderes públicos aragoneses es, conforme al artículo $24 \mathrm{c}$ ), «a garantizar la igualdad entre el hombre y la mujer en todos los ámbitos, con atención especial a la educación, el acceso al empleo y las condiciones de trabajo».

Al igual que en otras reformas de los Estatutos de Autonomía, son competencia exclusiva de la Comunidad Autónoma de Aragón las "políticas de igualdad social, que comprenden el establecimiento de medidas de discriminación positiva, prevención y protección social ante todo tipo de violencia, y, especialmente la de género» (art. 71.37. $\left.{ }^{\mathrm{a}}\right)$.

Poco antes de la realización de esta reforma, en Aragón ya había sido aprobada una Ley de violencia de género, la de 22 de marzo de $2007^{75}$, con el objeto de adoptar medidas integrales para la sensibilización, prevención y erradicación de la violencia ejercida sobre las mujeres.

Asimismo, la reforma del Estatuto de Autonomía de Castilla y León de $2007^{76}$, en su artículo 14, prohíbe cualquier discriminación por razón de género, garantizando la transversalidad del principio de igualdad de género en todas sus políticas, "promoviendo acciones positivas para lograr la igualdad de oportunidades entre mujeres y hombres, sobre todo en los ámbitos educativo, económico, laboral, en la vida pública, en el medio rural, en relación con la salud y con los colectivos de mujeres en situación de necesidad especial, particularmente las víctimas de violencia de género».

${ }^{73}$ Ley 12/2007, de 26 de noviembre, para la promoción de la igualdad de género en Andalucía. BOE núm., 38, de 13 de febrero de 2008. Ley 13/2007, de 26 de noviembre, de medidas de prevención y protección integral contra la violencia de género. $B O E$ núm., 38, de 13 de febrero de 2008.

74 Ley Orgánica 5/2017, de 20 de abril, de reforma del Estatuto de Autonomía de Aragón. $B O E$ núm. 97, de 23 de abril de 2007.

75 Ley 4/2007, de 22 de marzo, de Prevención y Protección integral de las Mujeres Víctimas de Violencia de Aragón. BOE núm. 141, de 13 de junio de 2007.

${ }^{76}$ Ley Orgánica 14/2007, de 30 de noviembre, de reforma del Estatuto de Autonomía de Castilla y León. BOE núm. 288, de 1 de diciembre de 2007. 
Se atribuye la Comunidad de Castilla y León la competencia exclusiva en la "promoción de la igualdad de trato y de oportunidades entre hombres y mujeres, con particular atención a las mujeres víctimas de la violencia de género» (art. 70.1.11.º.

También en esta Comunidad Autónoma, cuando fue aprobada la reforma de su Estatuto de Autonomía, estaba vigente una Ley, de 3 de marzo de $2003^{77}$, de igualdad de mujeres y hombres. Con posterioridad, en el ańo 2010, se aprobó una Ley contra la violencia de género ${ }^{78}$.

La reforma del Estatuto de Autonomía de Canarias del año 2018 ${ }^{79}$, en el artículo 11, recoge el derecho a la no discriminación por razón del sexo, y el artículo 17 establece que los poderes públicos "garantizarán la igualdad efectiva entre mujeres y hombres en el ámbito público y privado, y velarán por la conciliación de la vida familiar y profesional». El mismo artículo prescribe "la adopción de medidas efectivas para educar en valores de igualdad no sexistas» y la realización de "políticas activas que proporcionen a las mujeres la protección integral a las víctimas de violencia machista, prestando especial atención a las medidas preventivas».

El acceso en condiciones de igualdad a la educación (art. 21.2), al ámbito laboral (art. 23), a la cultura (art. 27), a los servicios sociales (art. 29) también recogido en esta reforma. En la que es un principio rector de la política del Gobierno «la igualdad entre hombres y mujeres en todos los ámbitos, en particular, en materia de empleo, trabajo y retribución» (art. 37.4).

Con anterioridad a esta reforma, la Comunidad de Canarias ya había aprobado una Ley de prevención y protección integral de las mujeres contra la violencia de género, la Ley de 8 de abril de $2003^{80}$. Ańos después, el 26 de febrero de $2010^{81}$, aprobó una Ley de igualdad entre hombres y mujeres.

En la Región de Murcia, en su Estatuto de Autonomía, tras la modificación realizada en el artículo 10 por una Ley de 1998, en su número Uno, apartado 20, se atribuye la competencia exclusiva a la Comunidad Autónoma en materia de "promoción de la mujer» ${ }^{82}$. Con posterioridad, una Ley de 4 de abril de 2007, de igualdad entre mujeres y hombres ${ }^{83}$, tiene como objetivo introducir el principio de

77 Ley $1 / 2003$, de 3 de marzo, de Igualdad de oportunidades entre mujeres y hombres en Castilla y León. BOE núm. 71, de 24 de marzo de 2003.

${ }^{78}$ Ley 13/2010, de 9 de diciembre, contra la violencia de género en Castilla y León. BOE núm. 317, de 30 de diciembre de 2010.

${ }^{79}$ Ley Orgánica 1/2018, de 5 de noviembre, de reforma del Estatuto de Autonomía de Canarias. BOE núm. 268, de 6 de noviembre de 2018.

${ }^{80}$ Ley 16/2003, de 8 de abril, de Prevención y Protección Integral de las Mujeres contra la Violencia de Género. BOE núm. 162, de 8 de julio de 2003.

${ }^{81}$ Ley $1 / 2010$, de 26 de febrero, canaria de igualdad entre mujeres y hombres. $B O E$ núm. 45, de 5 de marzo de 2010.

${ }^{82}$ Ley Orgánica 4/1982, de 9 de junio, de Estatuto de Autonomía para la Región de Murcia. $B O E$ núm. 146, de 19 de junio de 1982. El artículo 10 se modifica por la Ley Orgánica 1/1998, de 15 de junio. $B O E$ núm. 143, de 16 de junio de 1998.

${ }^{83}$ Ley $7 / 2007$, de 4 de abril, para la Igualdad entre Mujeres y Hombres, y de Protección contra la Violencia de Género en la Región de Murcia. BOE núm. 176, de 22 de julio de 2008. 
transversalidad y, en consecuencia, aplicar la perspectiva de género en las distintas fases de la planificación y ejecución de todas las políticas públicas.

El Estatuto de Autonomía de Castilla-La Mancha, en su artículo Cuarto. Tres, establece que la Junta de Comunidades «propiciará la efectiva igualdad del hombre y de la mujer, promoviendo la plena incorporación de ésta a la vida social y superando cualquier discriminación laboral, cultural, económica o política» ${ }^{84}$. En tanto que una Ley de 18 de diciembre de $2010^{85}$ establece el derecho de igualdad y no discriminación por razón del sexo, y contiene medidas activas para implementar la igualdad, medidas contra la discriminación por razón del sexo, e introduce procedimientos con tal finalidad, al tiempo que refuerza las instituciones de promoción de la igualdad.

En la Comunidad Autónoma de Extremadura, una reforma de su Estatuto realizada en $2011^{86}$ dice, en su artículo 7 n. ${ }^{\circ} 12$, que es un «objetivo irrenunciable que informará todas las políticas regionales y prácticas institucionales, la plena y efectiva igualdad de la mujer en todos los ámbitos de la vida pública, familiar, social, laboral, económica y cultural». Y promueve una política activa para remover los obstáculos que impidan o dificulten la igualdad real y efectiva. Siendo, como otros Estatutos, competencia exclusiva de la Comunidad Autónoma, las políticas de igualdad de género (art. 9.29). Pocos meses después de la aprobación del Estatuto, se aprueba la Ley de 23 de marzo de 2011, de Igualdad entre mujeres y hombres y contra la violencia de género ${ }^{87}$.

En otras Comunidades Autónomas, aunque no se recoge expresamente en sus Estatutos de Autonomía la igualdad entre mujeres y hombres, o la protección contra la violencia de género, existen otras leyes específicas sobre la materia. Es el caso de Navarra, donde las Leyes Forales 22/2002, de 2 de julio, y la Ley Foral $12 / 2003^{88}$, que modifica la anterior, adoptan medidas para la sensibilización, prevención y erradicación de la violencia sexista.

En la Comunidad cántabra, la Ley de Cantabria 1/2004, de 1 de abril ${ }^{89}$, tiene como objeto la adopción de medidas integrales para la sensibilización, prevención y erradicación de la violencia de género, protección, atención y asistencia a las víctimas, hijos, hijas, o personas sujetas a su tutela o acogimiento.

${ }^{84}$ Ley Orgánica 9/1982, de 10 de agosto, de Estatuto de Autonomía de Castilla-La Mancha. BOE núm. 195, de 16 de agosto de 1982 .

${ }^{85}$ Ley 12/2010, de 18 de noviembre, de igualdad entre mujeres y hombres de Castilla-La Mancha. BOE núm. 37, de 12 de febrero de 2011.

${ }^{86}$ Ley Orgánica 1/2011, de 28 de enero, de reforma del Estatuto de Autonomía de la Comunidad Autónoma de Extremadura. BOE núm. 25, de 29 de enero de 2011.

${ }^{87}$ Ley 8/2011, de 23 de marzo, de Igualdad entre mujeres y hombres y contra la violencia de género en Extremadura. BOE núm. 88, de 13 de abril de 2011.

${ }^{88}$ Ley Foral 12/2003, de 7 de marzo, de modificación de la Ley Foral 22/2002, de 2 de julio, para la adopción de medidas integrales contra la violencia sexista. $B O E$ núm. 99 , de 25 de abril de 2003.

${ }^{89}$ Ley $1 / 2004$, de 1 abril, Integral para la Prevención de la Violencia Contra las Mujeres y la Protección a sus Víctimas. BOE núm. 101, de 26 de abril de 2004. 
Galicia cuenta, desde el 16 de julio de 2004, con una Ley para la igualdad de mujeres y hombres ${ }^{90}$, y desde el 27 de julio de 2007, con otra para la prevención y tratamiento integral de la violencia de género ${ }^{91}$.

En Euskadi, con el objeto de establecer los principios generales que han de presidir los poderes públicos en materia de igualdad de mujeres y hombres, y establecer una serie de medidas dirigidas a promover y garantizar la igualdad de oportunidades y trato en todos los ámbitos de la vida, promover la autonomía y fortalecer la posición social, económica y política de las mujeres, se aprobó la Ley para la Igualdad de Mujeres y Hombres de 18 de febrero de $2005^{92}$.

De similar manera, la Comunidad de Madrid, con la finalidad de prevenir la violencia de género, lograr una protección integral de las víctimas y combatir todos los aspectos, causas y manifestaciones de este fenómeno, aprobó la Ley de 20 de diciembre de $2005^{93}$.

En Asturias, el 11 de marzo de 2011, se aprobó una Ley para la Igualdad de mujeres y hombres y la erradicación de la violencia de género ${ }^{94}$, para promover la igualdad a través de políticas públicas y adoptar medidas activas para la sensibilización, prevención y erradicación de la violencia de género.

Este recorrido, aunque superficial, da una clara idea del compromiso del legislador autonómico, de igual forma que el estatal, en promover la igualdad de mujeres y hombres y erradicar la violencia de género. Un compromiso y avance legislativo que no deja de contrastar con los numerosos casos de violencia de género que se están produciendo en España, y de los que se hacen eco constantemente los medios informativos.

\section{REFLEXIONES SOCIOPOLÍTICAS ACERCA DE LA LEGISLACIÓN SOBRE LA IGUALDAD JURÍDICA DE LA MUJER EN ESPAÑA}

\subsection{Resumen Del CONTEXTo GLOBAL}

Un análisis profundo de la legislación sobre la igualdad jurídica de la mujer en España no estaría completo sin su adecuada contextualización dentro del movimiento occidental más amplio hacia los derechos de las mujeres que comenzó en

${ }^{90}$ Ley $7 / 2004$, de 16 de julio, gallega para la igualdad de mujeres y hombres. BOE núm. 228, de 21 de septiembre de 2004.

${ }^{91}$ Ley $11 / 2007$, de 27 de julio gallega para la prevención y el tratamiento integral de la violencia de género. $B O E$ núm. 226, de 20 de septiembre de 2007.

${ }_{92}$ Ley 4/2005, de 18 de febrero, para la Igualdad de Mujeres y Hombres. BOPV núm. 42, de 2 de marzo de 2005.

${ }^{93}$ Ley $5 / 2005$, de 20 de diciembre, integral contra la violencia de género de la Comunidad de Madrid. BOE núm. 52, de 2 de marzo de 2006.

${ }_{94}$ Ley $2 / 2011$, de 11 de marzo, para la igualdad de mujeres y hombres y la erradicación de la violencia de género. BOE núm. 106, de 4 de mayo de 2011. 
las últimas décadas del siglo xix. Aunque los vestigios monárquicos permanecen hasta la actualidad en muchos países, la gobernación republicana, en sus varias formas, se popularizaba tanto que se instituía casi universalmente en el mundo occidental durante los siglos XIX y xx. A medida que abundaba el republicanismo, rápidamente se hizo evidente que la igualdad era un elemento necesario para la gobernación democrática. Los países que intentaban mantener antiguas castas de desigualdad, tanto cultural como legislativa, se deterioraban en confusión política y social. Reconociendo la igualdad en la naturaleza inherente de la democracia misma, las leyes de sufragio femenino fueron codificadas en muchos países occidentales a principios del siglo xx. Tanto el movimiento hacia el republicanismo como los sucesivos movimientos por los derechos de las mujeres fueron interrumpidos por, y luego acelerados debido a, las dos guerras mundiales. Sin embargo, en el caso de España, los avances logrados durante la Segunda República en la década de los treinta fueron frenados y totalmente revertidos por cuarenta años durante la dictadura de Francisco Franco.

Como se demostrará en las siguientes reflexiones, el apoyo cultural para los derechos de las mujeres en España crecía a pasos agigantados durante la dictadura, incluso mientras las mujeres españolas sufrían injusticias imperdonables impuestas por Franco en cumplimiento con su visión de la mujer como figura sumisa y secundaria en la sociedad. Aunque los millones de proponentes de la igualdad para las mujeres se veían obligados a guardar silencio por el temor legítimo a represalias violentas por parte de la aparentemente omnipresente dictadura, la evolución de las normas culturales, debido en gran parte al contacto con turistas de otros países occidentales ya en pleno movimiento de liberalización, fueron tan evidentes que incluso Franco sintió la necesidad de al menos fingir interés en los derechos de las mujeres. Los gestos legislativos tímidos y superficiales mencionados anteriormente se produjeron antes de la muerte de Franco en aparente respuesta a presiones tanto nacionales como internacionales. Esta pequeńa ola de legislación, mayormente simbólica, presagió el cambio gigantesco que llegaría a España tras la muerte de Franco.

Casualmente, el fallecimiento de Franco se produjo once meses después del comienzo del Año Internacional de la Mujer (AIM) y la iniciativa de las Naciones Unidas llamada la Década para la Mujer. La democracia en España volvió en un momento en el que el mundo occidental había decidido unirse colectivamente para trabajar proactivamente para proteger y empoderar a las mujeres. Dado que muchos países habían aprobado leyes para la protección de los derechos de las mujeres en los años anteriores, España tuvo varios ejemplos claros de cómo rápidamente codificar constitucionalmente la igualdad de las mujeres y luego reforzar esas protecciones a través de legislación subsecuente más exhaustiva y explícita. Aunque es común y lógico que los movimientos de igualdad ganen impulso al comienzo de una democracia, la velocidad y minuciosidad con que España aprobó las leyes de derechos de las mujeres fue impresionante. Esta muy rápida transición sirve como prueba de que una gran mayoría de espańoles, forzados violentamente a guardar silencio durante décadas, habían anhelado la libertad, la democracia, y la igualdad. Tres años después de la dictadura, la aprobación unánime de las disposiciones sobre la igualdad 
de la mujer en la nueva Constitución progresiva llevó a España a la vanguardia del movimiento internacional para los derechos de la mujer y convirtió al país en el ejemplo más claro de la eficacia de la acción democrática colectiva.

Finalmente, a medida que han pasado las décadas, España ha consolidado su reputación como uno de los líderes mundiales de gobernación en términos de los derechos de las mujeres. Como se mostró con la ágil transición, el gobierno casi siempre está guiado por la cultura una vez que se establece la democracia. Sin embargo, en las primeras dos décadas del siglo XxI, el gobierno español ha tomado medidas afirmativas para combatir el azote cultural en curso de la violencia de género y el machismo. Debido a que esta legislación aún está en un estado inicial, se requerirán futuras investigaciones para determinar la eficacia de esta estrategia que invierte la relación tradicional entre el gobierno y la cultura.

\subsection{EL SUFRAGIO FEMENINO EN EL MUNDO OCCIDENTAL}

Aunque al final del siglo xvin se instituyó, de una forma muy limitada, con éxito en los Estados Unidos y se intentó con efectos desastrosos en Francia, la democracia no se hizo ampliamente popular en el mundo occidental hasta finales del siglo XIX y principios del xx. En este momento, los países de América y Europa establecieron una gobernación democrática a diversos grados y estructuras. En Europa, muchos monarcas mantenían su poder en papeles más ceremoniales, mientras que los líderes militares tenían un papel importante en la supervisión de los gobiernos semidemocráticos o pseudodemocráticos en América Central y América del Sur. Con muy pocas excepciones, el derecho al voto en estas nuevas democracias se limitaba a porciones de la población en función de muchos factores, como la raza, la propiedad de la tierra, la nobleza, la educación y, por supuesto, el sexo. Sin embargo, la porción de la población con el derecho al voto se daba cuenta rápidamente, y en la mayoría de los casos se veían obligados a darse cuenta, de que la inclusión de todos los ciudadanos en las decisiones de una sociedad es una faceta esencial de la propia naturaleza de la gobernación democrática. Pronto se hizo evidente en todo el Occidente que la democracia no podría mantenerse por mucho tiempo sin el pleno derecho de voto de todos sus ciudadanos. En otras palabras, parece que la democracia, inevitablemente, tiende a dar la bienvenida a todos. Teniendo esto en cuenta, los movimientos de sufragio femenino comenzaron en un país tras otro demandando su derecho al voto y sus derechos básicos como seres humanos.

El hecho desafortunado sobre la naturaleza acogedora de la democracia es que las mujeres, a menudo, han sido las últimas en recibir la bienvenida a participar. El derecho al voto se ha otorgado comúnmente en el siguiente orden: primero, los reyes y la nobleza, luego los terratenientes varones, entonces los hombres educados de alta estima en la sociedad, después generalmente los hombres blancos en el Occidente, luego los hombres de origen minoritario racial y étnico, y, finalmente, las mujeres, pero a menudo con restricciones en cuanto a edad, educación, y/o estado civil. Con el tiempo, los criterios para el votante se liberalizaban a medida que mayores porcentajes de la población exigían el derecho al voto. Lo que a veces 
era un proceso lento, históricamente se aceleraba, o en el caso de España, revertió, debido a macroeventos como las depresiones económicas o, como fue el caso en Inglaterra, una guerra.

Durante siglos, aunque los ingleses en general mantenían una apreciación cultural por la noción de los derechos individuales desde la Magna Carta Libertatum en 1215, el gobierno del país estaba dominado por los monarcas hasta que la Revolución inglesa del siglo XVir lo obligó a aceptar la democracia de forma limitada. Con la democratización de la información provocada por la imprenta de Gutenberg en el siglo xv, el Occidente comenzó su cuenta atrás hacia la gobernación democrática. Los movimientos que seguían como la Reforma Protestante y la Ilustración revolucionaban el carácter mismo de la sociedad europea. Aun así, los monarcas podían mantener su poder, casi total, en el continente hasta el siglo XIX. Aunque varios cuerpos legislativos, de una forma u otra, existían en Inglaterra durante siglos, estos cuerpos estaban formados por duques y otros nobles que aún respondían al monarca y actuaban en su nombre. La implementación exitosa de un gobierno representativo en los Estados Unidos en 1789, incluidas las prohibiciones explícitas de los títulos de nobleza, sirvió como ejemplo para el resto del Occidente de que era posible lograr una gobernación democrática. Con el ejemplo de su antigua colonia en mente, el pueblo de Inglaterra, empezando con los hombres terratenientes sin títulos de nobleza, comenzó a exigir el derecho a votar por su propia representación en el Parlamento. La presión del pueblo se hizo tan grande que el parlamento bajo el rey Guillermo IV sintió la necesidad de aprobar la Ley de Reforma de 1832, otorgando el derecho al voto a algunos terratenientes. Esta legislación marcó el punto en el que Inglaterra realmente comenzó su lenta marcha hacia la democracia. Durante la segunda mitad del siglo xix, surgían una serie de protestas y movimientos exigiendo el derecho al voto, pero sus peticiones fueron en vano ${ }^{95}$. No fue hasta que Inglaterra se encontró en medio de una crisis electoral provocada por la «Gran Guerra» que los manifestantes finalmente prevalecieron. Ya años después del comienzo de la Primera Guerra Mundial, el Parlamento inglés aprobó reformas electorales extensas en la Ley de Representación del Pueblo de 1918. Esta legislación fue necesaria debido a la gran cantidad de hombres con derecho a voto que estaban en el extranjero luchando en la guerra. No se produjo por voluntad democrática, sino por temor a un colapso total del sistema electoral. Con tan pocos votantes elegibles en el país en ese momento, los resultados de las elecciones habrían sido injustamente sesgados, pero tampoco había suficientes personas con la capacidad de administrar las elecciones en sí. La legislación eliminó las restricciones previas al derecho de voto relacionadas con la propiedad de los hombres de los veintiún años o más, y permitió una edad menor, los diecinueve, para los soldados que estaban en el extranjero para que pudieran votar en ausencia. Al dar a todos los hombres el derecho al voto, cambiaron por completo la noción inglesa de la participación democrática de una

95 Mitchell, J.C. (1976), «Electoral Strategy Under Open Voting: Evidence from England», 1832-1880, Public Choice, 28 (invierno), pp. 17-35. p. 18. 
relación de propiedad a un derecho básico de todos los seres humanos. Además, este cambio de mentalidad afirmó el argumento de las sufragistas feministas, que también ganaron el derecho al voto con esta ley, aunque con serias restricciones sobre la edad, treinta en lugar de veintiuno, y restricciones basadas en si una mujer ocupaba su propio hogar ${ }^{96}$. Las sufragistas feministas, que formaron una parte clave del éxito de Inglaterra durante la Primera Guerra Mundial, no estaban satisfechas con este progreso, dado que los nuevos estándares seguían concretizando la desigualdad en ley. Continuaban solicitando al gobierno y protestando hasta que las restricciones electorales a las mujeres inglesas fueron eliminadas por completo por el gobierno conservador de Stanley Baldwin, que aprobó en el Parlamento la Ley de Igualdad del Derecho al Voto de $1928^{97}$. Así como la Primera Guerra Mundial se convirtió en el catalizador final para el derecho al voto femenino en Inglaterra, esta misma guerra sirvió como el argumento final para las sufragistas feministas en los Estados Unidos, también.

El servicio al país de las mujeres trabajadoras durante la Primera Guerra Mundial dejó al gobierno estadounidense sin otra opción que aprobar el sufragio femenino con la ratificación de la Enmienda XIX a la Constitución en agosto de 1920, pero esta victoria solo llegó después de décadas de manifestaciones y un proceso gradualista parecido al de los ingleses. Como no había reyes ni títulos de nobleza en la República estadounidense, el sufragio se limitó originalmente a los terratenientes blancos y varones. Aunque a la mayoría de los estadounidenses todavía no se les permitía votar durante el primer siglo de existencia del país, la primera enmienda a la Constitución les garantizaba el derecho a la libertad de expresión. A su vez, la conversación política colectiva durante este tiempo estaba dominada más por un tema que por cualquier otro, el de la abolición de la esclavitud ${ }^{98}$. La institución de la esclavitud, el "pecado original» del país, se convirtió en un tema tan divisivo que, para detener su expansión en los territorios recientemente establecidos en el oeste, Estados Unidos entró en su única guerra civil. Después de varios años de batallas brutales y cientos de miles de muertes, la guerra culminó con una victoria para el norte abolicionista y la aprobación de varias enmiendas constitucionales que liberaron a las personas esclavizadas y les otorgó a estos esclavos recién liberados los mismos derechos que los ciudadanos, siempre y cuando esas personas eran hombres. Las tres enmiendas aprobadas en los años posteriores a la guerra fueron la Enmienda XIII, que liberó a todos los esclavos en 1865; la Enmienda XIV, que confirió la igualdad de derechos como ciudadanos a los esclavos liberados en 1868; y la Enmienda xv, que otorgó el sufragio a los exesclavos recién liberados en 1870 . Como a menudo era el caso de la Constitución estadounidense, el lenguaje de estas

${ }^{6}$ Ogg, F.A. (ago. 1918), "The British Representation of the People Act.», The American Political Science Review, 12(3), pp. 498-503.

${ }_{97}$ Takayanagi, M. (2019), “"Does the right hon. Gentleman mean equal votes at 21?” Conservative women and equal franchise, 1919-1928", Women's History Review, 28(2), pp. 194-214. p. 194.

${ }^{98}$ La Constitución de los Estados Unidos de América (1787), Archivos Nacionales de los Estados Unidos de América. https://www.archives.gov/espanol/constitucion. 
enmiendas se redactó de manera deliberadamente amplia para establecer una base legal para los derechos de ciudadanía sin limitar esos derechos con demasiada especificidad. En parte, la Enmienda XIV decía: «Todas las personas nacidas o naturalizadas en los Estados Unidos y algunas veces a su jurisdicción son ciudadanos de los Estados Unidos y de los Estados en que residen». Esta enmienda se refería a "personas» sin referencia específica al sexo. Además, la Enmienda Xv decía lo siguiente: «Ni los Estados Unidos, ni ningún otro Estado, pueden desconocer ni menoscabar el derecho de sufragio de los ciudadanos de los Estados Unidos por motivo de raza, color o de su condición anterior de esclavos». Debido a que este lenguaje era tan amplio, estas dos enmiendas se convirtieron inmediatamente en el argumento principal para el sufragio femenino.

El 5 de noviembre de 1872, dos años después de la ratificación de la Enmienda xv, la famosa sufragista Susan B. Anthony, que había viajado por el país durante décadas dando discursos a favor de la igualdad de derechos para las mujeres, fue a las urnas y votó. Con este simple acto, ella causó una gran controversia en la ciudad y, tres semanas después, fue arrestada por el delito de votar siendo una mujer. Durante el juicio, Anthony propuso el argumento conciso de que la Enmienda XIV se refería a todas las "personas» como ciudadanos, no solo a los hombres. Por lo tanto, las mujeres estadounidenses eran claramente ciudadanas y tenían sufragio de acuerdo con la Enmienda Xv. Sin mucha explicación para su veredicto, el juez decidió que Anthony era culpable del crimen de haber votado siendo mujer y la castigó con una multa de $\$ 100$, igual a aproximadamente $2000 €$ cuando se ajusta por inflación. Anthony declaró que nunca pagaría un duro de una multa tan injusta y, entendiendo las probables consecuencias políticas y sociales, el juez la dejó libre sin haber pagado un céntimo ${ }^{99}$. Después del juicio, Susan B. Anthony continuaba viajando por el país dando discursos y escribiendo artículos a favor del sufragio femenino. Aunque lamentablemente falleció catorce años antes de que su sueño de sufragio universal se hiciera realidad, sus palabras, y las de muchas otras sufragistas, no cayeron en oídos sordos. Varios estados recién fundados en el oeste del país aprobaron el sufragio femenino en las siguientes décadas. Primero Colorado en 1893, luego Washington y California en 1910 y, finalmente, cuando el movimiento volvió al este del país, el estado liberal de Nueva York lo aprobó en 1917, solo tres años antes de que se aprobara el sufragio completo a nivel nacional mediante la ratificación de la Enmienda XIX a la Constitución en 1920. En el caso de los Estados Unidos, el sistema federal descentralizado tenía un efecto positivo para el movimiento por los derechos de las mujeres. Sin embargo, en otros países occidentales, este no era siempre el caso.

Debido en gran parte a su sistema descentralizado, Suiza tiene el curioso deshonor de no haber logrado completamente el sufragio femenino hasta noviembre de 1990. Los hombres suizos recibieron el sufragio universal a través de una

99 Ritchie, J. y Ronald, K. (eds.) (2001), Available Means: An Anthology of Women's Rhetoric(s), Pittsburgh, University of Pittsburgh Press, pp. 151-156. 
enmienda constitucional en 1848, aunque podían votar antes en muchas áreas del país. Mientras pasaban las décadas, el sistema suizo funcionaba de una forma muy democrática, al menos desde la perspectiva de los hombres, ya que celebraban referéndums sobre importantes asuntos nacionales, cantonales y municipales. En 1910, movimientos de sufragio femenino comenzaron a nivel municipal y cantonal, pero ni siquiera hubo una conversación sobre el sufragio femenino en el Parlamento suizo hasta 1944. En ese momento, el tema se mencionaba de vez en cuando a nivel nacional, pero el gobierno federal anunció en 1951 que era demasiado pronto para celebrar un referéndum sobre el sufragio femenino. Durante la década de los cincuenta, los cantones empezaron a aprobar derechos de voto limitados para las mujeres, lo que llevó a los líderes políticos a pensar que había llegado el momento para un referéndum nacional. En 1959, los hombres del país se reunieron en las plazas de cada ciudad para participar, no por votación secreta sino por aclamación pública delante de las mujeres suizas, y votaron abrumadoramente, dos hombres en contra para cada hombre a favor, en contra del sufragio femenino. En todo el Occidente, la década de los sesenta fue una década turbulenta de manifestaciones enormes y exitosos movimientos de justicia social. Se estaba produciendo un cambio transcendental hacia la protección de los derechos de todos los seres humanos, y en 1968 los países europeos se unieron para firmar una declaración de derechos en la Convención Europea de Derechos Humanos. Este fue un documento que el gobierno suizo no pudo apoyar sin agregar excepciones para excluir los derechos políticos de las mujeres. Indignados y en un estado de shock, los partidarios del sufragio femenino en toda Europa se unieron a los sufragistas suizos para presionar al Parlamento para que finalmente otorgue a las mujeres el derecho al voto. La presión fue tan grande que solo tres años después, el 7 de febrero de 1971, los hombres del país votaron, esta vez dos hombres a favor para cada hombre en contra, aprobar el sufragio femenino. Aunque este fue un momento emocionante para las mujeres del país, no fue una victoria completa. El referéndum todavía permitió a los cantones decidir sus propias reglas de votación para las elecciones locales y para una cámara del Parlamento nacional. Cuatro cantones decidieron mantener prohibiciones al sufragio femenino, dos de ellos eliminaron estas prohibiciones en 1983. Pasaron más años hasta que el cantón de Appenzell Ausserrhoden aprobó el sufragio femenino en 1989 y Appenzell Innerrhoden finalmente trajo el sufragio universal a Suiza el 27 de noviembre de $1990^{100}$. Dada su reputación como un país progresista e iluminado, este aspecto desafortunado de su historia puede ser sorprendente a muchas personas. Por otro lado, el estereotipo de España como un país conservador y atrasado puede necesitar revisión, dado el hecho de que aprobó dos veces el sufragio femenino sin restricción ninguna décadas antes de que los suizos reconocieran este derecho humano básico.

100 Banaszak, L.A. (1996), Chapter Title: Comparing the U.S. and Swiss Woman Suffrage Movements, Why Movements Succeed or Fail: Opportunity, Culture, and the Struggle for Woman Suffrage (pp. 3-20), Nueva Jersey, Princeton University Press. 
En 1931, en los inicios de la naciente República española, cuando se debatieron las disposiciones sobre el sufragio femenino de la nueva Constitución, la decisión de los progresistas se centró en un debate entre ideología y practicidad. Muchas feministas y partidarios acérrimos del sufragio femenino se preocupaban de que habría consecuencias prácticas serias si les dieran a las mujeres españolas el derecho al voto. Hablando del punto de vista feminista, dijo Margarita Nelken en su libro La mujer ante las Cortes Constituyentes (1931), "facilitarle el voto a la mujer suponía darle votos a las fuerzas conservadoras. Desde su argumentación, "darle derechos a un colectivo no significaba necesariamente actuar a favor del conjunto de la sociedad... Las mujeres españolas realmente amantes de la libertad han de ser las primeras en posponer su interés propio al progreso de España"». Las fuerzas progresistas, con quienes Nelken se identificó, temían que las esposas de los hombres conservadores, especialmente en las zonas rurales del país, simplemente votaran como les dijeron sus esposos. Serían esposas obedientes y sumisas de acuerdo con sus creencias católicas. Muchas mujeres progresistas favorecían un periodo durante el cual a las mujeres no se les permitiría votar, sino que tendrían tiempo para ser generalmente educadas, casi el cuarenta por ciento de las mujeres españolas en 1930 de diez años o más eran analfabetas, y también culturalmente informadas de sus derechos ${ }^{101}$. Fue una decisión difícil que muchas feministas progresistas, como Victoria Kent, lamentaron tener que tomar: "Creo que no es el momento de otorgar el voto a la mujer española. Lo dice una mujer que, en el momento crítico de decirlo, renuncia a un ideal. Al expresarme así hago renuncia de mi ideal femenino, pero así requiero la salud de la República». Por otro lado, hubo muchas sufragistas feministas que se negaron a renunciar a sus ideales en lugar de la practicidad política: "Clara Campoamor contestó a estos argumentos críticos en la defensa del carácter indiscutible del sufragio femenino, si se partía en la nueva organización política del principio de igualdad como derecho universal, con independencia de si sus resultados electorales eran oportunos o no. Su defensa fue de carácter ideológico y ético, y radicalmente democrática» ${ }^{102}$. Al final, el sufragio femenino se aprobó como una disposición de la Constitución de la Segunda República española. Durante los siguientes años, los temores de muchas feministas progresistas se hicieron realidad a medida que los partidos conservadores ganaron varias elecciones, y las visiones increíblemente divergentes del país se convirtieron en tumultos violentos. Una situación muy parecida había confrontado a los redactores de la Constitución estadounidense con respecto al tema de la esclavitud. Muchos estaban en contra de la esclavitud y querían prohibirla en la Constitución como una afirmación de los derechos de todos los seres humanos. Sin embargo, sabiendo que los estados del sur no firmarían una Constitución que prohibiera la esclavitud, el

101 Viñao Frago, A. (Winter 1990), «The History of Literacy in Spain: Evolution, Traits, and Questions», History of Education Quarterly, 30(4), pp. 573-599. p. 584.

102 Aguado, A. (2005), «Entre lo público y lo privado: sufragio y divorcio en la Segunda República», Ayer, 60, pp. 105-134. p. 116. 
resto de los estados favoreció la practicidad sobre la ideología, temiendo que, como estados divididos, pronto serían conquistados por países europeos poderosos. Siete décadas después, esta decisión llevó al país a su única guerra civil. Aunque es un tema muy debatido, algunas académicas proponen el argumento de que, en el caso de España, la decisión contraria a favorecer el principio sobre la practicidad fue una de las causas de la guerra civil española ${ }^{103}$. Con el establecimiento de la dictadura de Francisco Franco, las mujeres de España no votarían otra vez de una forma verdaderamente libre durante cuatro largas décadas.

\subsection{LA REPRESIÓN DE LAS MUJERES EN LA ESPAÑA FRANQUISTA}

Durante los cinco años de la Segunda República española, España descubrió lo que sucede a menudo en muchos países que no están acostumbrados a la gobernanza democrática, que la libertad crea derechos e igualdad, pero también puede ser desordenada y caótica. Esta desafortunada realidad se desarrolló en la República española, ya que estos años se vieron empañados por la violencia entre facciones y elecciones disputadas. Utilizando el desorden natural de la nueva democracia como una excusa para imponer su versión fascista de la ley y el orden, el general Francisco Franco estableció una dictadura en 1939 después de tres años de sangrienta guerra civil. Durante los primeros años del franquismo, las fuerzas de la dictadura asesinaron indiscriminadamente a miles de ciudadanos españoles como medio para eliminar la oposición ideológica y generar temor en sus opositores políticos restantes. El horror de las fosas comunes aún sin descubrir es el triste legado de esta época. La violencia de Franco se dirigió contra hombres y mujeres por igual, pero después de la «limpieza» política de los primeros años de su dictadura, su enfoque totalitario se volvió hacia la imposición de sus creencias sociales represivas sobre las mujeres.

La España de los años cuarenta fue marcada por la institucionalización sistemática de una visión sexista y religiosa del papel de la mujer en la sociedad. Franco creía que las mujeres debían cumplir con las normas de género católicas y subordinarse por completo al hombre. Según su ideología, las mujeres no eran consideradas ciudadanas, ni siquiera seres humanos en muchos casos: «La subordinación de la mujer al hombre era total. Las tres funciones que tenía asignadas -madre, esposa y ama de casa- representaban la expresión máxima de la feminidad $»^{104}$. Al igual que otros dictadores fascistas europeos del siglo xx, Franco estaba obsesionado con la idea del cuerpo sano de la mujer como necesidad para ejercer un estado centralizado. Con esto en mente, Franco empleó a la Sección Femenina para crear periódi-

${ }_{103}$ Wyoming Fees, E. (2007), Making Women Matter: Spain's Long Road Toward Gender Equality, Chapel Hill, University of North Carolina. pp. 6-7.

104 Pelka, A. (2014), «Mujer e ideología en la posguerra española: feminidad, cuerpo y vestido", Historia Social, 79, pp. 23-42. p. 27. 
cos y revistas propagandizadas para inculcar a las mujeres españolas el mensaje de que el mantenimiento de un cuerpo sano es una parte clave de su servicio al país:

Según Foucault, en las sociedades modernas la forma represiva del poder se centra en la 'administración del cuerpo', incluyendo su formación y su control... Siguiendo Foucault, a causa de esta bio-politica la mujer era percibida en relación a su cuerpo, transmisor además de los valores del régimen. Se promovía un cuerpo sano y funcional, paradigma de la 'raza' y al servicio de la nación por media de dicha función procreadora ${ }^{105}$.

La "administración del cuerpo» no era solo una estrategia política de un gobierno fascista a nivel macro, sino la reducción de las mujeres como seres humanos a sus funciones biológicas, una eliminación de la humanidad de las mujeres a nivel psicológico y emocional. En la España franquista, las mujeres fueron bombardeadas constantemente con el mensaje de que su importancia no solo era servir como máquinas biológicas irreflexivas para el estado, sino que deberían estar agradecidas por este papel en la sociedad: «La verdadera misión de la mujer es dar hijos a La Patria. Y esto es, por lo tanto, su suprema aspiración» ${ }^{106}$. La ideología del régimen franquista con respecto a las mujeres lo llevó a eliminar casi totalmente los derechos legales de las mujeres, así como a establecer una serie de leyes sobre las relaciones familiares que desgarraron la estructura misma de la sociedad. Las leyes aprobadas por la dictadura en el Código penal de 1944 sobre violación y adulterio convirtieron la tragedia personal de las mujeres españolas en profundas injusticias sociales. Por ejemplo, "las leyes penales franquistas asimilaban las mujeres a los incapaces y además sólo daban protección a las mujeres que eran consideradas "honestas", ya que si no lo eran, eran tratadas como un simple objeto, a disposición del varón, quien podía incluso llegar a violar a su mujer sin temor a ser sancionado penalmente» ${ }^{107}$. La falta de castigo legal para un esposo que abusó violentamente a su esposa es lo que Marta Borraz llamó «la doble represión de Franco sobre la mujer» ${ }^{108}$. El sufrimiento emocional personal de una mujer violada se multiplicó por el sello de aprobación del gobierno de las horribles acciones del hombre. La disposición del Código penal de 1944 sobre el adulterio es otro ejemplo de esta doble represión. Si una mujer casada cometiera adulterio de cualquier manera o en cualquier lugar, no solo sería penalizada con una pena de prisión menor, sino que el matrimonio podría declararse nulo. Si un hombre casado cometió adulterio, se agregaron dos condiciones para exculparlo de su culpabilidad. Mientras el hombre tuviera su relación extramarital fuera del hogar conyugal y no lo hiciera "notoriamente», es decir, si lo hiciera

105 Ibidem, p. 25.

106 Ibidem, p. 25.

107 Moraga García, M.A. (dic. 2008), «Notas sobre la situación jurídica de la mujer en el franquismo", Feminismo/s, 12, pp. 229-252. p. 240.

108 Borraz, M., «La doble represión de Franco sobre la mujer», ElDiario.es. https://desmemoria.eldiario.es/represion-mujeres/. 
discretamente, no podría ser legalmente responsable de adulterio. La institucionalización de protecciones legales tan desiguales fue en contra de todos los conceptos modernos de moralidad y contra la naturaleza humana misma. Aunque no podían afectar el cambio legislativo durante el régimen franquista, tener que soportar tales injusticias durante varias décadas provocó un cambio importante en el sentimiento cultural con respecto a la igualdad de las mujeres en Espańa. Después de la muerte de Franco, motivó a las mujeres espańolas a exigir cambios, y motivó a los hombres españoles a apoyar la causa de la igualdad de las mujeres.

Durante la década de los sesenta, se hizo evidente que Franco sentía presión a nivel nacional por un cambio de sentimiento público en su país y, además, las democracias occidentales internacionales empezaron a codificar su liberalización cultural. A principios de la década, Franco aprobó legislación supuestamente sobre los derechos de las mujeres en la Ley del 22 de julio de 1961, «la mencionada Ley recogió el principio de la igualdad de derechos laborales de los trabajadores de ambos sexos, si bien estableció excepciones significativas» ${ }^{109}$. Estas excepciones significativas incluían una amplia parte del poder gubernamental del país, como juez, fiscal, y la gran mayoría de los puestos en las fuerzas armadas. Aunque estos cambios fueron en gran medida simbólicos y superficiales, es digno de mención que Franco sentía que era necesario al menos seńalar que apoyaba un movimiento afirmando los derechos de las mujeres. Estos cambios a la ley española iban en contra de su visión sexista y demostraron que incluso Franco reconocía que un movimiento hacia la igualdad era inevitable. Además del cambio en el sentimiento cultural debido a décadas viviendo bajo leyes injustas, la dependencia económica de Franco con el turismo hizo que la población de España tuviera un intercambio cultural con ciudadanos de países más liberales todos los días. En las décadas de los cincuenta y los sesenta, la estrategia de crecimiento económico de Franco dependía en gran medida de la floreciente industria del turismo. El número de turistas extranjeros visitando España pasó de solo 20000 en 1940 a 460000 en 1950, a 4,33 millones en 1960, y luego a 21,27 millones en 1970. Estas cifras representan un aumento asombroso de 4,624\% en las dos décadas de 1950 a $1970^{110}$. Los millones de turistas que Franco quería para estimular la actividad económica también trajeron millones de interacciones con los españoles a diario. Aunque todavía hay debate sobre el grado de liberalismo en la cultura espańola durante la Segunda República, no hay duda de que la economía de Franco irónicamente movió la cultura a favorecer a los derechos de las mujeres, tanto que la cultura española apoyó completamente la igualdad para las mujeres en el momento en que murió Franco. Además, dado que las mujeres sufrían tanto bajo el franquismo, es apropiado que el año de su muerte, 1975, fuera declarado por las Naciones Unidas como el Año Internacional de la Mujer.

109 Valiente Fernández, C. (1998), «La liberalización del régimen franquista: la Ley de 22 de Julio de 1961 sobre los derechos Políticos, profesionales y de trabajo de la mujer», Historia Social, 31, pp. 45-65. p. 45.

${ }_{110}$ Vallejo Pousada, R. (2015), «¿Bendición del cielo o plaga? El turismo en la España franquista, 1939-1975», Cuadernos de Historia Contemporánea, 37, pp. 89-113. p. 92. 


\subsection{LA INFLUENCIA INTERNACIONAL EN LA LEGISLACIÓN ESPAÑOLA SOBRE LOS DERECHOS DE LAS MUJERES DESPUÉS DE FranCo}

Tras la muerte de Franco, España se apresuró a establecer un gobierno representativo y estructurar una Constitución justa que incluyera la protección de los derechos de todos los ciudadanos. En la década y media anterior a la redacción de la Constitución española de 1978, varios países occidentales habían aprobado legislación importante sobre la igualdad y los derechos de la mujer, dando a los españoles un resumen detallado de las disposiciones necesarias para garantizar la igualdad. Además, se estaba formando un esfuerzo internacional concertado para reconocer y promover una visión de las mujeres empoderadas, y para proteger los derechos de las mujeres instando a las legislaturas a aprobar las leyes de derechos de las mujeres.

En 1975, las Naciones Unidas comenzó un proyecto de diez años para promover y proteger a las mujeres en todo el mundo. La ONU declaró a 1975 el Año Internacional de la Mujer. Luego estableció el 8 de marzo como el Día Internacional de la Mujer, una celebración anual de las mujeres y sus logros sociales, económicos, políticos y culturales. Finalmente, la ONU anunció su proyecto llamado la Década para la Mujer. Este proyecto estableció objetivos elevados en su conferencia inicial en la Ciudad de México en 1975, evaluó y actualizó esos objetivos en una reunión en Copenhague en 1980, y examinó los resultados y estableció objetivos futuros durante su convención final en Nairobi en 1985. Esta década crucial culminó con la ratificación por 170 naciones en 1985 de la Convención de las Naciones Unidas sobre la eliminación de todas las formas de discriminación contra la mujer. Los documentos ratificados incluían disposiciones para la inclusión de «departamentos para mujeres» y el nombramiento de ministras en todas las organizaciones internacionales, la continuación del aumento de la sensibilización colectiva con respecto a los problemas de las mujeres a través de mujeres empoderadas en imágenes en los libros de texto y mensajes positivos hacia las mujeres en todos los planes de estudio educativos y, finalmente, una Declaración de los Derechos de la Mujer junto con un Pacto para proteger esos derechos ${ }^{111}$. Durante la Década para la Mujer, numerosos países, España incluido, aprobaron legislación amplia sobre los derechos de las mujeres, demostrando que la acción colectiva a nivel macro puede, de hecho, producir un cambio positivo.

Al elaborar su nueva Constitución, España no solo contó con el apoyo de las Naciones Unidas y la comunidad internacional, sino que tuvo la ventaja de aprender de los ejemplos establecidos por las leyes sobre los derechos de las mujeres que ya se habían aprobado en otros países occidentales. Los constituyentes españoles no tenían que reinventar la rueda y ciertamente no lo hicieron. Dado que el lenguaje final de los artículos relacionados con la igualdad de las mujeres en la Constitu-

111 Zinsser, J.P. (nov. 1990), «The United Nations Decade for Women: A Quiet Revolution", The History Teacher, 24(1), pp. 19-29, pp. 20-22. 
ción española de 1978 es sorprendentemente similar al de la legislación anterior de otros países, uno debe inferir que los constituyentes españoles fueron muy influenciados por sus homólogos extranjeros. Por ejemplo, las disposiciones de igualdad de la Constitución italiana de 1947 dicen lo siguiente:

Art. 3: Todos los ciudadanos tendrán la misma dignidad social y serán iguales ante la ley, sin distinción de sexo, raza, lengua, religión, opiniones políticas ni circunstancias personales y sociales. Constituye obligación de la República suprimir los obstáculos de orden económico y social que, limitando de hecho la libertad y la igualdad de los ciudadanos, impiden el pleno desarrollo de la persona humana y la participación efectiva de todos los trabajadores en la organización política, económica y social del país.

Art. 37: La mujer trabajadora tendrá los mismos derechos y, a igualdad de trabajo, la misma retribución que el trabajador. Las condiciones de trabajo deberán permitir a la mujer el cumplimiento de su misión familiar esencial y asegurar a la madre y al niño una protección especial adecuada ${ }^{112}$.

El lenguaje de la Constitución italiana de 1947 es casi idéntico a partes de la ley de Derechos Civiles de 1964 en los Estados Unidos, y casi se copian y pegan palabra por palabra luego en el Artículo 14 de la Constitución española de 1978. Aunque las protecciones constitucionales transmiten seriedad y permanencia, España volvería a seguir el ejemplo de sus vecinos occidentales al agregar un lenguaje más específico y aplicable en la legislación de los años siguientes.

$\mathrm{Al}$ aprobar la Ley de Igualdad Salarial en 1963 y la extensa Ley de Derechos Civiles de 1964, Estados Unidos comenzó la tradición occidental de aprobar una serie de leyes de igualdad de derechos específicos y numerosos. Aunque el partido republicano había intentado aprobar una serie de leyes de igualdad racial durante la década de los cincuenta, fueron impedidos cada vez por los demócratas racistas del sur, conocidos coloquialmente como los Dixiecrats. Con la llegada del progresista presidente Kennedy en 1960, la legislación sobre igualdad racial y del sexo se convirtió en una prioridad compartida para ambos partidos. Los dos partidos trabajaron juntos para redactar una legislación detallada y aprobaron la Ley de Igualdad Salarial de 1963 con una abrumadora mayoría de aprobación del 97,6\%. Todos los republicanos presentes votaron a favor y solo nueve demócratas votaron en contra de la igualdad salarial para las mujeres trabajadoras. Siguiendo el ejemplo de los Estados Unidos, el Reino Unido aprobó su Ley de Igualdad Salarial en 1970 y la Ley de Discriminación Sexual en $1975^{113}$ y Francia, estableciendo disposiciones similares a las de los Estados Unidos y el Reino Unido, aprobó legislación sobre la

112 Constitución de la República Italiana (27 dic. 1947), Consejo Económico y Social de España. http://www.ces.es/TRESMED/docum/ita-cttn-esp.pdf.

${ }_{113}$ Ross, J. (2010), 10 Discrimination, Employment Law Essentials (pp. 163-200), Edinburgh, Edinburgh University Press, p. 164. 
igualdad salarial en diciembre de $1972^{114}$. En todos estos países, estas políticas han sido muy difíciles de aplicar y, por lo tanto, leyes más estrictas de igualdad salarial han sido objeto de mucho debate hasta la actualidad.

Debido a su tradición de valorar mucho la propiedad privada y la preferencia histórica para los derechos negativos en la legislación, Estados Unidos no llegó a muchas disposiciones de derechos afirmativos que luego se agregaron a la serie de leyes en muchos países europeos. Aunque EE. UU. estableció Medicare y Medicaid en 1965, opciones públicas para el seguro médico, la mayoría de los estadounidenses todavía obtienen su seguro médico a través de sus empleadores, que a menudo son empresas privadas. Debido a este dominio privado del mercado de sanidad, aún no se ha instituido la baja por maternidad remunerada con legislación federal. Sin embargo, Europa es y ha sido más abierta culturalmente y políticamente a la intervención pública, este problema se resolvió hace mucho tiempo. En Francia, por ejemplo, el debate se centró menos en si una solución socializada era aconsejable y más en cómo mantener la igualdad judicial cuando se trata de un derecho afirmativo directamente relacionado con la biología de las mujeres. Dorothy McBride Stetson explicó el debate en su libro Los derechos de las mujeres en Francia, diciendo que incluso en el nuevo clima de la ley de igualdad de oportunidades en el empleo, la baja por maternidad remunerada sigue siendo una parte central de la política laboral francesa, mientras que en los Estados Unidos las leyes de igualdad en el empleo han desplazado la baja por maternidad como tal. Las mujeres empleadas en Francia hoy tienen derecho por ley a una baja por maternidad pagada de catorce semanas. De hecho, en 1975, bajo Giscard, se fortalecieron las protecciones para el embarazo y la maternidad. Sin embargo, en 1977, una medida patrocinada por el gobierno para la baja por maternidad adicional para las madres fue cuestionada por opositores que preferían hacerla una baja "parental», disponible también para los padres, y esta solución prevaleción ${ }^{15}$. La baja por maternidad remunerada fue solo uno de los temas que se abordaron en una larga serie de leyes de derechos de la mujer aprobadas en Francia de 1965 a 1985. Cada política que afectaba a las mujeres, desde la reproducción hasta la jubilación, fue reescrita durante estas dos décadas ${ }^{116}$. Antes de casi todos los otros países con respecto a este tema, España ha obligado legalmente a la baja por maternidad remunerada de una forma u otra desde $1930^{117}$.

Aunque el progreso para las mujeres españolas fue interrumpido por cuarenta años de dictadura violenta, el país se apresuró a constitucionalizar y legis-

114 Van der Vleuten, A. (2016), The Price of Gender Equality: Member States and Governance in the European Union, New York: Routledge. (Originalmente publicado en 2007, Farnham, Reino Unido, Ashgate), p. 80.

115 Offen, K. (1990), Book Review: Women's Rights in France by Dorothy McBride, Constitutional Commentary, 7(130), pp. 130-136, p. 135.

116 Ibidem, p. 131.

117 Espuny Tomás, M.J. (2006), Los antecedentes históricos al permiso de lactancia, IUS Labor, 2, p. 3. 
lar protecciones de igualdad de derechos para las mujeres al mismo tiempo que la mayoría del resto del mundo occidental. Apenas tres años después de la muerte de Franco, España aprobó el sufragio universal sin restricciones dentro de un sistema verdaderamente democrático, así como amplias protecciones de los derechos de las mujeres. La velocidad y la relativa facilidad con que España aprobó estas leyes mostraron que una gran mayoría de la población española apoyaba la igualdad para las mujeres y no estaba de acuerdo con la visión de Franco para el país. Los españoles se vieron obligados a guardar silencio, reprimidos durante décadas, pero tan pronto como la democracia volvió a España, rápidamente el país se convirtió en uno de los líderes mundiales con respecto a la legislación sobre los derechos de las mujeres, aprobando tales medidas aproximadamente al mismo tiempo que la mayoría del Occidente, e incluso antes de algunos países, como Australia, que no aprobó su Ley de Discriminación por Sexo hasta 1984. En una democracia, una cultura a menudo cambia mucho antes que el gobierno, pero el progreso en España se detuvo debido a la dictadura. Ya sea debido a una reacción visceral y moral a las leyes injustas del franquismo o al contacto personal con millones de turistas más liberales, está claro que la cultura española no aceptó el franquismo y anhelaba la igualdad y la libertad después de la opresión de Franco. En otras palabras, España no era Franco y Franco no era España.

\section{CONCLUSIONES}

Después de un análisis exhaustivo de la evolución de la legislación sobre los derechos de las mujeres dentro del contexto más amplio del movimiento de igualdad de las mujeres de Occidente, parece que existen razones para ser optimistas sobre el futuro de la igualdad y el empoderamiento de las mujeres. Los resultados de esta investigación también indican que puede ser el momento de revisitar la memoria histórica sobre la cultura española. Dos veces durante el siglo pasado, España llegó a establecer una gobernanza democrática y, en ambas ocasiones, el país avanzó rápidamente e inequívocamente hacia la igualdad de los sexos. Esta observación debería alentar a todo el mundo sobre el posible progreso futuro de tal país. Aun así, la igualdad ante la ley no siempre equivale a la igualdad práctica en la sociedad. Los medios españoles hacen bien en arrojar luz sobre el grave problema del feminicidio por violencia doméstica, pero muchas otras mujeres sufren de otras formas comunes del maltrato. Por ejemplo, la pareja les impide ver a la familia o tener relaciones con amigos, insultos o amenazas, decide las cosas que puede o no hacer, insiste en tener relaciones sexuales aunque no tienen ganas, o a veces produce miedo por su comportamiento agresivo ${ }^{118}$.

118 Osborne, R. (2009), Apuntes sobre la violencia de género, Barcelona, Edicions Bellaterra, pp. 94-95. 
Con problemas sociales como estos que aún perviven en España, el gobierno español tomó medidas proactivas al aprobar las leyes orgánicas de 2004 y 2007 en un intento por resolver estas cuestiones. Como se mencionó anteriormente, el orden normal en democracia es que la cultura cambie primero y luego solicite al gobierno que promulgue esos cambios legislativamente. Sin embargo, la estrategia de las leyes orgánicas invierte esta relación con el objetivo de lograr en mayor medida la igualdad práctica en la sociedad española. Como Juan José Solozábal Echavarría escribió sobre el tema en 2013:

La igualdad, además, es una aspiración irrenunciable del constitucionalismo y ocupa un lugar central en el Estado social como forma política de nuestros días, que se propone intervenir en la marcha de la sociedad y corregir las desigualdades e injusticias que se dan en ella... Desde el punto de vista individual el Estado moderno es una comunidad jurídica de iguales, que no tolera la desigualdad jurídica personal, pues la igualdad es una exigencia del reconocimiento de la dignidad de todos ${ }^{119}$.

El éxito de un proyecto que busca reconocer la dignidad de todos sus ciudadanos es vital no solo para la seguridad y el bienestar de las mujeres que sufren directamente este problema, sino para la salud de una democracia que funcione:

La construcción de una sociedad igualitaria y libre de violencia no es algo que pueda hacerse a 'coste cero', la igualdad precisa de una inversión que permita abordar el cambio implicando a toda la sociedad, porque la igualdad es la base de la democracia y la violencia de género cuestiona la misma democracia. Mientras las mujeres sigan siendo asesinadas por el hecho de ser mujeres, no se puede hablar de democracia sin abrir debates sociales, políticos y económicos para cuestionar el patriarcado, como sistema económico y político ${ }^{120}$.

Las leyes orgánicas de 2004 y 2007 son emblemáticas del reconocimiento del gobierno español de la necesidad de estos debates. Es demasiado pronto para saber si estas políticas proactivas y una relación invertida entre el gobierno y la cultura serán efectivas, pero hay algunos indicadores de que la sociedad se está moviendo en la dirección correcta. Aunque el número de mujeres asesinadas por la violencia doméstica en España ha disminuido solo marginalmente en los últimos ańos, el número de denuncias totales y denuncias presentadas por terceros ha aumentado dramáticamente desde $2015^{121}$. Esto sirve como prueba de una creciente conciencia sobre los derechos y el bienestar de las mujeres, pero futuras investigaciones tendrán que

119 Solozábal Echavarría, J.J. (2013), Capitulo segundo: la garantía de la igualdad. Los derechos fundamentales: La vida, la igualdady los derechos de libertad, García Guerrero, J.L. (dir.), Valencia, Tirant lo Blanch, pp. 75-76.

120 Tajahuerce Ângel, I. y Ramírez Rico, E. (2018), La intervención en violencia de género desde diversos ámbitos, TAMaYo, J.J. (dir.), Madrid, Dykinson, S.L. p. 17.

${ }^{121}$ Violencia de género -datos y estadísticas-. (25 nov. 2019). epdata. https://www.epdata. es/datos/violencia-genero-estadisticas-ultima-victima/109/espana/106\#. 
determinar la eficacia a largo plazo de estas leyes. Finalmente, como lo demostró este análisis, la acción colectiva a escala internacional ha funcionado para abordar problemas parecidos en el pasado y, por lo tanto, puede ser una estrategia efectiva en la búsqueda de soluciones en el futuro.

ReCibido: 01-05-2020; ACEPTADo: 29-06-2020 
